\title{
LÍGIA PELOSI MENDONÇA
}

Repercussões morfológicas da subnutrição proteica e da dieta padrão de Moçambique no nervo isquiático de ratos nos períodos pré e pós-natal 


\section{LÍGIA PELOSI MENDONÇA}

\section{Repercussões morfológicas da subnutrição proteica e da dieta padrão de Moçambique no nervo isquiático de ratos nos períodos pré e pós-natal}

\begin{abstract}
Dissertação apresentada ao Programa de Pós-Graduação em Anatomia dos Animais Domésticos e Silvestres da Faculdade de Medicina Veterinária e Zootecnia da Universidade de São Paulo para a obtenção do título de Mestre em Ciências
\end{abstract}

Departamento:

Cirurgia

Área de concentração:

Anatomia dos Animais Domésticos e Silvestres

Orientador:

Prof. Dr. Edson Aparecido Liberti 
Autorizo a reprodução parcial ou total desta obra, para fins acadêmicos, desde que citada a fonte.

\section{DADOS INTERNACIONAIS DE CATALOGAÇÃO-NA-PUBLICAÇÃO}

(Biblioteca Virginie Buff D’Ápice da Faculdade de Medicina Veterinária e Zootecnia da Universidade de São Paulo)

Mendonça, Lígia Pelosi

Repercussões morfológicas da subnutrição proteica e da dieta padrão de Moçambique no nervo isquiático de ratos nos períodos pré e pós-natal / Lígia Pelosi Mendonça. -- 2015.

$81 \mathrm{f}$. :il.

Dissertação (Mestrado) - Universidade de São Paulo. Faculdade de Medicina Veterinária e Zootecnia. Departamento de Cirurgia, São Paulo, 2015.

Programa de Pós-Graduação: Anatomia dos Animais Domésticos e Silvestres.

Área de concentração: Anatomia dos Animais Domésticos e Silvestres.

Orientador:. Prof. Dr. Edson Aparecido Liberti.

1. Subnutrição proteica. 2. Dieta de Moçambique. 3. Nervo isquiático. I. Título. 


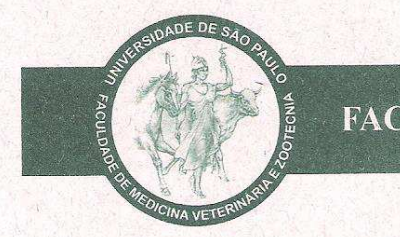

UNIVERSIDADE DE SÃO PAULO

\section{Comissão de Ética no uso de animais}

\section{CERTIFICADO}

Certificamos que o Projeto intitulado "Repercussões morfológicas da desnutrição proteica e da dieta padrão de Moçambique no nervo isquiático de ratos nos períodos pré e pós-natal", protocolado sob o no 2939/2013, utilizando 45 (quarenta e cinco) ratos, sob a responsabilidade do(a) Prof. Dr. Edson Aparecido Liberti, está de acordo com os princípios éticos de experimentação animal da "Comissão de Ética no uso de animais" da Faculdade de Medicina Veterinária e Zootecnia da Universidade de São Paulo e foi aprovado em reunião de 13/3/2013.

We certify that the Research "Morphological aspects of the protein malnutrition and diet in default of Mazombique in sciatic nerve of rats during periods pre and post-natal", protocol number 2939/2013, utilizing 45 (forty five) rats, under the responsibility Prof. Dr. Edson Aparecido Liberti, agree with Ethical Principles in Animal Research adopted by "Ethic Committee in the use of animals" of the School of Veterinary Medicine and Animal Science of University of São Paulo and was approved in the meeting of day 3/13/2013.

São Paulo, 18 de março de 2013.

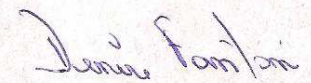

Denise Tabacchi Fantoni

Presidente 


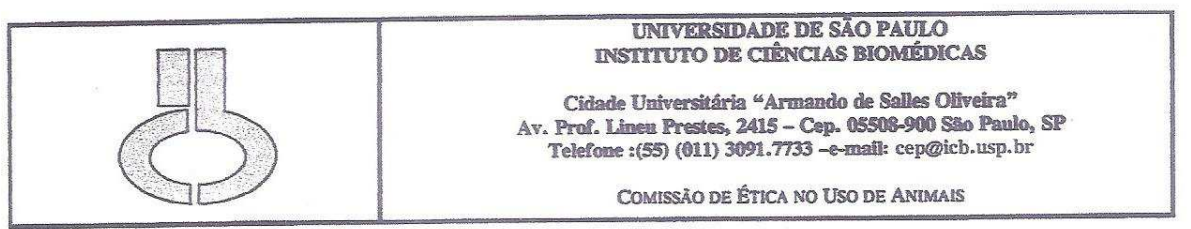

Dec1. CEUA.013/2013.

DECLARAÇ Ã O

Em adendo ao Certificado 020/12/CEUA, aprovado em 26.03.12, e por solicitação do Prof. Dr. Edson Aparecido Liberti, responsável pela limha de Pesquisa, autorizo a inclusẫo de Ligia Pelosi Mendonça, Lidia dos Santos Rocha Cruz e Luliana Ribeiro ao Projeto de Pesquisa "Análise morfoquantitativa e ultraestrutural dos componentes do plexo mioentérico do intestino delgado de ratos submetidos à dieta padrão de moçambique nos períodos pré e pós-natal", uma vez que se trata de utilização da mesma espécie animal e de métodos experimentais similares ao Projeto.

São Paulo, 05 de março de 2013.

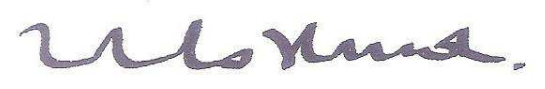

Prof. Dr. Wothan Tavares de Lima Coordenador da CEUA ICB/USP 


\section{Dedicatóría}

Àquele que tem toda honra, que me conduziu pelos melhores caminhos, permaneceu ao meu lado sustentando-me nas fraquezas e me fazendo perceber que cada dificuldade é um aprendizado, um degrau de subida que se torna muito mais suave em sua presença. Dedico a Ele, o Senhor Deus, dono de minhas escolhas. 


\section{FOLHA DE AVALIAÇÃO}

Autor: MENDONÇA, Lígia Pelosi

Título: Repercussões morfológicas da subnutrição proteica e da dieta padrão de Moçambique no nervo isquiático de ratos nos períodos pré e pósnatal

Dissertação apresentada ao Programa de Pós-Graduação em Anatomia dos Animais Domésticos e Silvestres da Faculdade de Medicina Veterinária e Zootecnia da Universidade de São Paulo para a obtenção do título de Mestre em Ciências

Data:

1

\section{Banca Examinadora}

Prof. Dr.

Instituição: Julgamento

Prof. Dr.

Instituição: Julgamento

Prof. Dr.

Instituição: Julgamento 


\section{AGRADEÇO ESPECIALMENTE:}

Ao Deus pai, a Jesus Cristo filho, que em único corpo, é meu grande mestre, aconselhador e motivador. Deu-me livramentos e bênçãos, me capacitou e me fez confiante em sua promessa. Agradeço Senhor, por colocar as pessoas certas em meu caminho, por permitir lhe conhecer e amar, por permitir compartilhar a GRAÇA de ser fiel a ti e poder viver todos os dias, os SEUS planos para mim.

A minha amada mãe Vânia, minha avó Neusa e minha irmã Loren. Muitas vezes as vi renunciando a própria vontade e necessidade para me dar condições de continuar, e inúmeras vezes tive prova de um amor incondicional. Vocês são preciosidades que o Senhor colocou em minha vida e o agradeço todos os dias pelo presente de tê-las caminhando ao meu lado. Obrigada e por me fazer conhecer o verdadeiro significado da palavra FAMÍLIA, obrigada pelo amor, carinho e apoio em minhas questões e escolhas. Amo vocês eternamente!

Ao meu namorado Arthur pelo imensurável carinho com que soube compreender minha ausência por diversas vezes, e muito além disso, por encher meu coração de alegria mesmo distante. Pelas palavras doces, enérgicas, e por aquelas que não foram ditas, todas elas em seu momento me trouxeram paz e segurança. Ao meu maior incentivador, meu grande alicerce, o meu amor, àquele que me espera pacientemente, meu MUITO OBRIGADA! Te amo!

Ao meu grande mestre e orientador Prof. Dr. Edson Aparecido Liberti. Meu maior respeito pelo seu caráter e dignidade, sua coragem em seguir em frente diante de tantas marcas e dores, o Senhor faz parte de minhas orações. Serei eternamente grata pela compreensão e ajuda quando ainda tentava entrar no mercado de trabalho, isso foi essencial! Agradeço por me permitir viver esta grande experiência que vai além das paredes do laboratório, seus exemplos e palavras serão sempre únicas e repetidas com carinho.

A toda família Mendonça, especialmente aos tios Célia e Eliezer, primos Érica, Leonardo, Renan e Matheus. A concretização deste trabalho não seria possível sem vocês. Em momento de instabilidade e fraqueza, vocês me deram muito além do abrigo, o conforto emocional e carinho de irmãos. Cada conversa despretensiosa, risada inocente, passeio, jantar me repunham as energias para mais uma semana. Obrigada a todos, por tudo! 


\section{AGRADEÇO:}

À Faculdade de Medicina Veterinária e Zootecnia da Universidade de São Paulo, por proporcionar um desenvolvimento científico, profissional e pessoal.

À Coordenação de Aperfeiçoamento de Pessoal de Nível Superior - CAPES, pelo auxílio concedido em forma de bolsa de estudos.

À Professora Doutora Maria Angélica Miglino pela oportunidade única, aceitandome como aluna do Programa de Pós-Graduação em Anatomia dos Animais Domésticos e Silvestres da Universidade de São Paulo, onde desempenha o importante papel de Coordenadora.

Aos mestres Silvia Lacchini e César Natal, obrigada pelo incentivo quanto a anatomia durante o Programa de Aperfeiçoamento de Ensino - PAE.

A todos os colegas do Laboratório de Anatomia Funcional Aplicada a Clínica e a Cirurgia - LAFACC, que se fizeram importantes muitas vezes por uma simples informação ou pequeno gesto de ajuda que facilitou o desenvolvimento das técnicas e processamento de materiais.

Em especial, àqueles que serão sempre mais que colegas, Liliana Ribeiro, Any Kelly Lima, Lídia Cruz, Flávio Tampelini, Josy Cal, Ricardo Bandeira, com quem pude compartilhar sinceramente aflições e alegrias de uma nova experiência. Vocês jamais serão esquecidos.

Aos funcionários do Biotério do Departamento de Anatomia do Instituto de Ciências Biomédicas da Universidade de São Paulo, Fábio França e Renivaldo de Souza, que com paciência, muito nos ensinaram sobre os animais experimentais.

Aos técnicos de laboratório do Departamento de Anatomia, Sebastião Boleta, Sônia Regina Yokomizo e Marta Maria Righetti pela paciência, dedicação e auxílio com as técnicas laboratoriais, sempre com grande disponibilidade.

A Sra. Rosana Duarte Prisco, que com impressionante destreza domina a informação estatística sem hesitar. Foram ensinamentos que guardarei com prazer em minha memória.

A Sra. Rose Elic que sempre disponível e bem humorada, num trabalho de qualidade, auxiliou com as fotografias de Microscopia Eletrônica. 
À amiga Malu Motta, funcionária do ICB/USP, obrigada pela amizade, ajuda e disponibilidade em momentos delicados.

Aos funcionários do ICB-USP e da FMVZ-USP, especialmente Maycon Barbosa, Jaqueline Martins, as bibliotecárias Elza e Neusa pela atenção, presteza e respeito pelos alunos. A ajuda de vocês foi de extrema importância.

Agradeço aos componentes da banca de defesa desta dissertação pela disponibilidade e atenção em participar deste momento. Muito obrigada!

A todos os contemporâneos colegas de pós-graduação da Anatomia dos Animais Domésticos e Silvestres, não vou nominá-los por temor de uma omissão involuntária, agradeço por fazerem parte desta história.

A todos aqueles que direta ou indiretamente contribuíram para a realização deste trabalho, tão importante para minha vida profissional, o meu sincero agradecimento. 
"Mas, buscai primeiro o reino de Deus, e sua justiça, e todas estas coisas vos serão acrescentadas."

Mateus 6:33 


\section{RESUMO}

MENDONÇA, L. P. Repercussões morfológicas da subnutrição proteica e da dieta padrão de Moçambique no nervo isquiático de ratos nos períodos pré e pós-natal. [Morphological effects of protein undernutrition and diet pattern of Mozambique in sciatic nerve of rats during periods pre and pos-natal]. 2015. $81 \mathrm{f}$. Dissertação (Mestrado em Ciências) - Faculdade de Medicina Veterinária e Zootecnia, Universidade de São Paulo, São Paulo, 2015.

A subnutrição é um quadro caracterizado por escassez proteico-calórica e sua manifestação na República de Moçambique é responsável por um terço das mortes de crianças com idade inferior a 5 anos. É a responsável pela falha no crescimento nos primeiros anos de vida e no Brasil, até 2011, era considerada um problema grave de saúde pública. $\mathrm{O}$ objetivo deste trabalho foi investigar possíveis repercussões no tecido nervoso periférico de ratos Wistar subnutridos, comparandoos com aqueles que receberam a dieta padrão de Moçambique (baseada em proteína vegetal) e com aqueles que receberam nutrição balanceada. Para a realização deste estudo foram utilizados 15 ratos machos da linhagem Wistar e as técnicas utilizadas foram: Microscopia Eletrônica de Transmissão e Varredura, possibilitando a aquisição de dados quantitativos e qualitativos, utilizando ainda princípios estereológicos. Os resultados demonstraram alterações morfológicas nos grupos $\mathrm{S}$ e $\mathrm{M}$, assim como diferenças quanto ao contorno das fibras nervosas e a disposição das camadas de mielina. Em relação ao peso e a ASTn, os três grupos são diferentes estatisticamente. Ao contrário, quanto à densidade de fibras nervosas mielínicas e ao número total estimado de fibras mielínicas, não houve diferença significante entre os grupos. Em relação à ASTax do nervo isquiático, houve significância entre os três grupos, já na análise da ASTbm e da ASTfm, houve diferença apenas entre os grupos $S \neq N, M \neq N$. Foi concluído, portanto que a subnutrição promoveu alterações morfológicas na estrutura do nervo isquiático e nas fibras nervosas mielínicas que podem ser irreparáveis, e numericamente gerou um mecanismo compensatório de aumento de densidade em relação a área do nervo, ou seja, um nervo de área menor, porém com fibras nervosas mais próximas, não havendo diferença na quantidade de fibras por nervo.

Palavras-chave: Subnutrição proteica. Dieta de Moçambique. Nervo isquiático. 


\begin{abstract}
MENDONÇA, L. P. Morphological effects of protein undernutrition and diet pattern of Mozambique in sciatic nerve of rats during periods pre and pos-natal. [Repercussões morfológicas da subnutrição proteica e da dieta padrão de Moçambique no nervo isquiático de ratos nos períodos pré e pós-natal]. 2015. $81 \mathrm{f}$. Dissertação (Mestrado em Ciências) - Faculdade de Medicina Veterinária e Zootecnia, Universidade de São Paulo, São Paulo, 2015.
\end{abstract}

Undernutrition is a condition characterized by protein-calorie shortage and its manifestation in the Republic of Mozambique is responsible for a third of deaths of children under the age of 5 years. It is responsible for growth failure early in life and in Brazil until 2011, was considered a serious public health problem. The objective of this study was to investigate possible effects on peripheral nerve tissue of Wistar rats undernourished, comparing them with those who received standard diet of Mozambique (based on vegetable protein) and those who received balanced nutrition. For this study were used 15 male rats of the Wistar and techniques used were: Transmission Electron Microscopy and Scanning, enabling acquisition of quantitative and qualitative data, using stereological principles. The results showed morphological changes in $\mathrm{S}$ and $\mathrm{M}$ groups as well as differences in the contour of nerve fibers and of the layers of myelin. In terms of weight and ASTn, the three groups are statistically different. Rather, density of myelinated nerve fibers and the estimated total number of myelinated fibers, not present significant difference between groups. Regarding ASTax sciatic nerve, there was significant difference between the three groups, and in the analysis of ASTms and ASTmf, there was difference only between the groups. It was concluded therefore that malnutrition promoted morphological changes in the sciatic nerve structure and myelin nerve fibers that may be irreparable, numerically generating a compensatory mechanism of density increase in relation to nerve area, in other words, a nerve smaller area but with next nerve fibers, with no difference in the number of nerve fibers by.

Key-words: Undernutrition protein. Diet Mozambique. Sciatic nerve. 


\section{LISTA DE FIGURAS}

Figura 1 - Localização de Moçambique no Continente Africano 26

Figura 2 - Representação gráfica do suprimento energético derivada de cereais, raízes e tubérculos (1990-1992 e 2007-2009) ....................27

Figura 3 - Mapa da fome .29

Figura 4 - Crianças com DPC tipo marasmo e kwashiorkor 31

Figura 5 - Representação da localização do nervo isquiático 34

Figura 6 - Fluxograma do período experimental - 2013 39

Figura 7 - Determinação da área seccional transversa do nervo isquiático (ASTn)

Figura 8 - Esquema ilustrativo do procedimento utilizado para a obtenção dos campos de amostragem ou dbs

Figura 9 - Determinação da área seccional transversa dos axônios (ASTax), das bainhas de mielina (ASTbm) e das fibras mielínicas (ASTfm) do nervo isquiático

Figura 10 - Ratos dos grupos N, M e S .50

Figura 11 - Microscopia Eletrônica de Transmissão .52

Figura 12 - Microscopia Eletrônica de Transmissão .53

Figura 13 - Representação gráfica das médias ( \pm desvio padrão) do peso corporal de animais dos grupos $\mathrm{N}, \mathrm{S}$ e M

Figura 14 - Representação gráfica das médias ( \pm desvio padrão) da área seccional transversa do nervo $(A)$ da densidade das fibras nervosas mielínicas $(B)$ e do número total estimado de fibras mielínicas $(C)$ do nervo isquiático dos animais dos grupos $\mathrm{N}, \mathrm{S}$ e $\mathrm{M}$

Figura 15 - Representação gráfica da distribuição de frequência da ASTax do nervo isquiático dos animais dos grupos $\mathrm{N}, \mathrm{S}$ e M

Figura 16 - Representação gráfica da distribuição de frequência da ASTbm do nervo isquiático dos animais dos grupos $\mathrm{N}, \mathrm{S}$ e M

Figura 17 - Representação gráfica da distribuição de frequência da ASTfm do nervo isquiático dos animais dos grupos $\mathrm{N}, \mathrm{S}$ e $\mathrm{M}$ 


\section{LISTA DE TABELAS}

Tabela 1 - Valores médios do peso corporal, da área seccional transversa do nervo, da densidade de fibras nervosas melínicas e do número total estimado de fibras mielínicas do nervo isquiático de animais dos grupos $\mathrm{N}, \mathrm{S}$ e M

Tabela 2 - Médias, desvios padrões, valores mínimos e máximos da área seccional transversa $\left(\mu \mathrm{m}^{2}\right)$ dos axônios das fibras nervosas mielínicas do nervo dos animais dos grupos $\mathrm{N}, \mathrm{S}$ e $\mathrm{M}$

Tabela 3 - Médias, desvios padrões, valores mínimos e máximos da área seccional transversa $\left(\mu \mathrm{m}^{2}\right)$ das bainhas de mielina das fibras nervosas mielínicas do nervo dos animais dos grupos $\mathrm{N}, \mathrm{S}$ e M

Tabela 4 - Médias, desvios padrões, valores mínimos e máximos da área seccional transversa $\left(\mu \mathrm{m}^{2}\right)$ das fibras nervosas mielínicas do nervo dos animais dos grupos $\mathrm{N}$, S e M 


\section{LISTA DE ABREVIATURAE E SIGLAS}

$\begin{array}{ll}\text { A }^{\prime} & \text { Área do db } \\ \text { A [tot] } & \text { Área seccional transversa total do nervo } \\ \text { ASTax } & \text { Área seccional transversa do axônio } \\ \text { ASTbm } & \text { Área seccional transversa da bainha de mielina } \\ \text { ASTfm } & \text { Área seccional transversa da fibra mielínica } \\ \text { ASTn } & \text { Área seccional transversa do nervo } \\ \text { CE } & \text { Coeficiente de erro } \\ \text { CO }_{2} & \text { Gás carbônico } \\ \text { DA } & \text { Desnutrição aguda } \\ \text { db } & \text { Disector bidimensional } \\ \text { dbi } & \text { Disector bidimensional inicial } \\ \text { DC } & \text { Desnutrição crônica } \\ \text { DEP } & \text { Desnutrição energético-proteica } \\ \text { DP } & \text { Desvio padrão }\end{array}$

FAO Food Alimentation Organization

MET Microscopia eletrônica de transmissão

MEV Microscopia eletrônica de varredura

$\mathrm{mm}^{2} \quad$ Milímetros quadrados

N' Número total de fibras mielínicas a partir de cada $\mathrm{db}$

$\mathrm{NaCL} \quad$ Cloreto de sódio

$\mathrm{NaOH} \quad$ Hidróxido de sódio

OMS Organização Mundial de Saúde

$\mathrm{OsO}_{4} \quad$ Tetróxido de ósmio

PBS Tampão Salina Fosfato

$\mathrm{pH} \quad$ Potencial Hidrogeniônico

Q' Número de fibras nervosas mielínicas somadas em um determinado db

SNP Sistema Nervoso Periférico

um Micrômetros 
$1 \quad$ INTRODUÇÃO

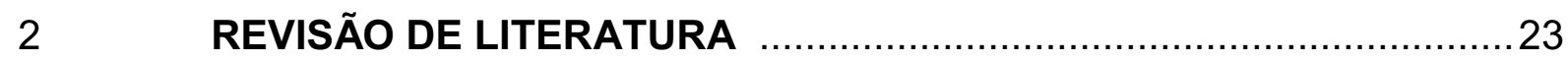

2.1 SUBNUTRIÇÃO: TERMINOLOGIA E CONCEITO …………………...23

2.2 SUBNUTRIÇÃO NO MUNDO E A DIETA PADRÃO DE

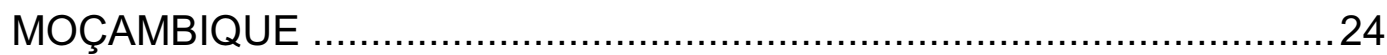

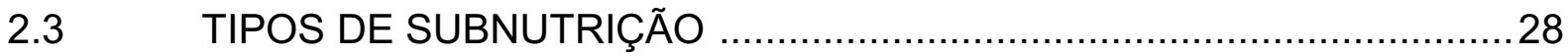

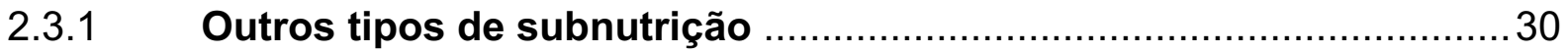

2.4 EVIDÊNCIAS SOBRE A INFLUÊNCIA DA SUBNUTRIÇÃO NO

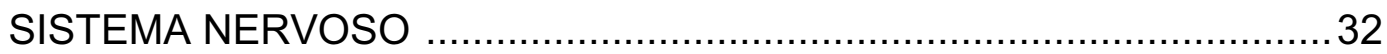

2.5 A PARTE PERIFÉRICA DO SISTEMA NERVOSO E O NERVO

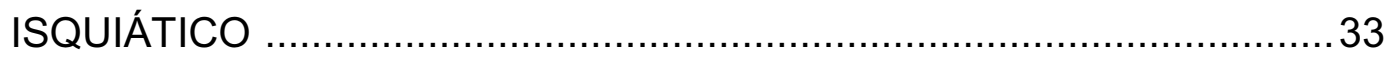

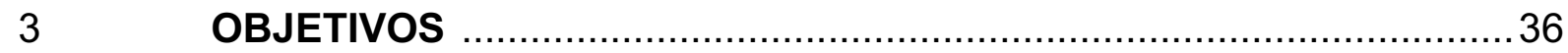

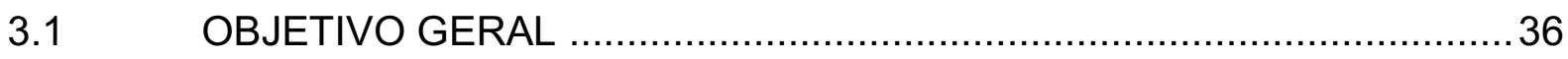

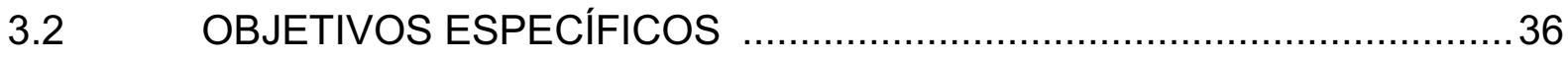

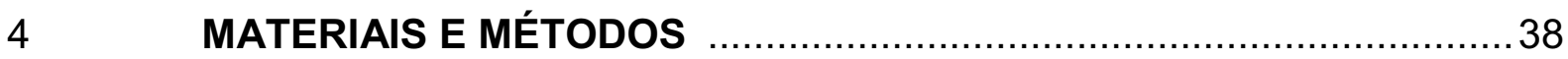

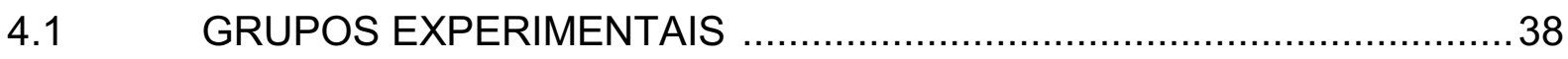

4.2 MICROSCOPIA ELETRÔNICA DE VARREDURA (MEV) ………..........40

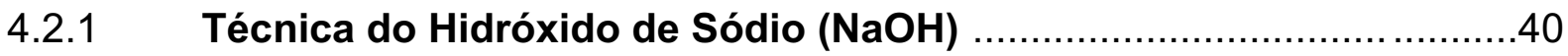

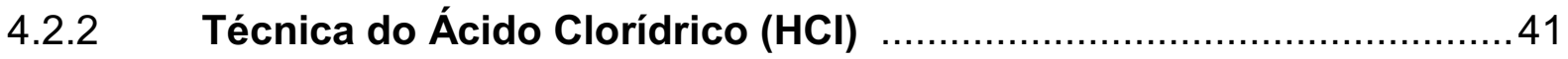

4.3 MICROSCOPIA ELETRÔNICA DE TRANSMISSÃO (MET) ……….......41

4.4 MORFOMETRIA E ESTEREOLOGIA …….................................42

4.4.1 Determinação da área seccional transversa do nervo isquiático (ASTn) 43

4.4.2 Determinação da densidade e do número total estimado de fibras nervosas mielínicas no nervo isquiático 
4.4.3 Determinação das áreas seccionais transversas dos axônios (ASTax), das bainhas de mielina (ASTbm) e das fibras mielínicas (ASTfm) do nervo isquiático

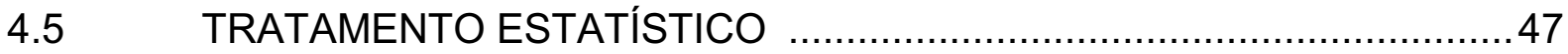

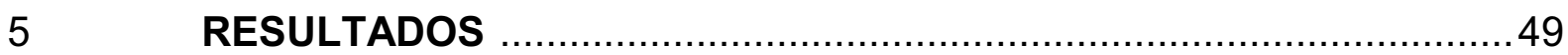

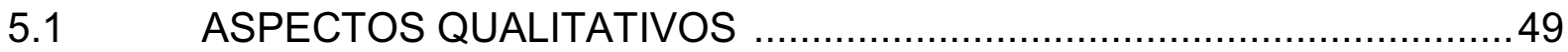

5.1.1 MICROSCPIA ELETRÔNICA DE TRANSMISSÃO (MET) ….................51

5.1.2 MICROSCOPIA ELETRÔNICA DE VARREDURA (MEV) $\ldots \ldots \ldots \ldots \ldots \ldots \ldots . . . . . . . . . .51$

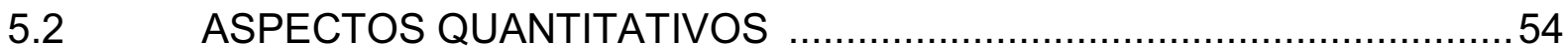

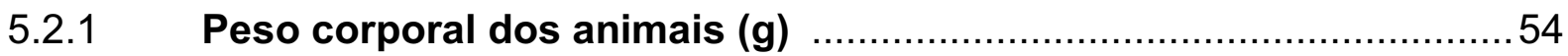

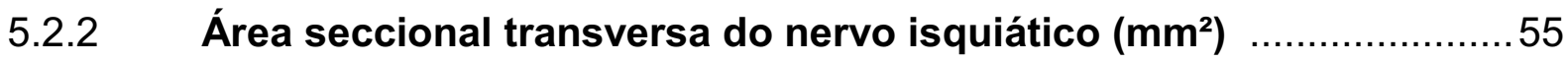

5.2.3 Densidade de fibras nervosas mielínicas (fibras $/ \mathrm{mm}^{2}$ ) $\ldots \ldots \ldots \ldots \ldots \ldots . \ldots 5$

5.2.4 Número total estimado de fibras nervosas mielínicas

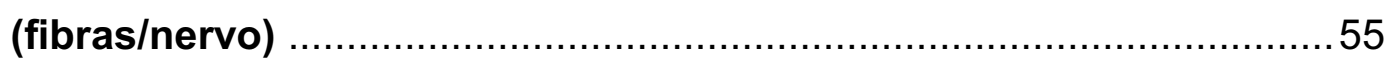

5.2.5 Área seccional transversa dos axônios das fibras mielínicas (ASTax) do nervo isquiático $\left(\mu \mathrm{m}^{2}\right)$

5.2.6 Área seccional transversa das bainhas de mielina das fibras mielínicas (ASTbm) do nervo isquiático $\left(\mu \mathrm{m}^{2}\right)$

5.2.7 Área seccional transversa das fibras mielínicas (ASTfm) do

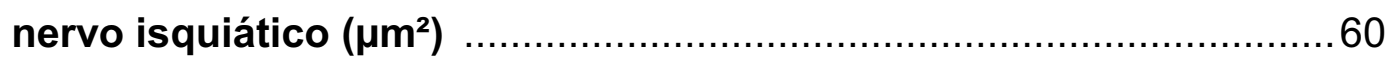

6 DISCUSSÃO

6.1 OBSERVAÇÕES GERAIS QUALITATIVAS E QUANTITATIVAS SOBRE O MODELO ANIMAL E O PROTOCOLO EXPERIMENTAL ......63

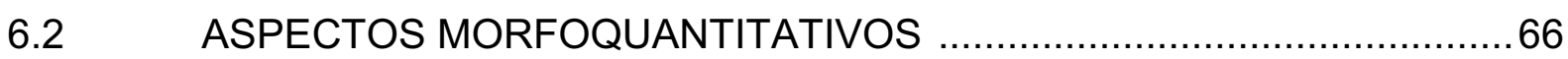

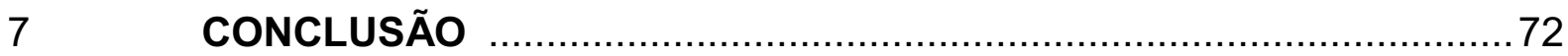

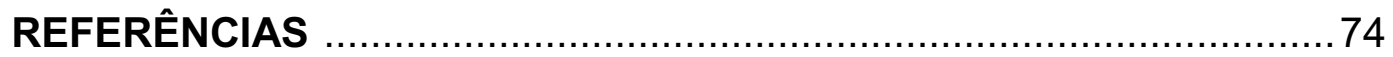


INTRODUÇÃO 


\section{INTRODUÇÃO}

A pobreza mundial ainda é um fator que exerce grande influência no estado nutricional dos indivíduos com baixa renda. Entre os anos de 2010 e 2012, uma em cada oito pessoas no mundo (aproximadamente 870 milhões) não consumiu em uma dieta, alimentos em quantidade suficiente para atender a exigência mínima de energia que seu corpo demanda. Destas, 852 milhões residiam em países em desenvolvimento. Porém, mesmo ainda com números alarmantes, pode-se dizer que a subnutrição caiu 36\% em relação aos anos de 1990 a 1992, referência estabelecida pelas metas de desenvolvimento do milênio (FAO, 2012).

A subnutrição, de acordo com a Organização Mundial de Saúde (WHO, 1982) é um quadro caracterizado por escassez proteico-calórica, e considerado um estado deficitário de nutrientes decorrente da má alimentação ou da baixa capacidade em absorver ou em utilizar os nutrientes ingeridos (STRATTON, 2005). Além de ser uma das principais causas de morte, a desnutrição crônica pode trazer danos irreversíveis à saúde durante todo o ciclo de vida, tais como: baixa estatura que dá origem ao fraco potencial físico para o trabalho; diminuição da função cognitiva resultando em um mau desempenho escolar, e maiores riscos de doenças degenerativas, como diabetes e obesidade (WHO, 2010).

Gobatto (1993) verificou em seres humanos e outros mamíferos, modificações metabólicas e endocrinológicas devido a baixa ingestão calórica ou proteica. Barker et al. (1993) e Barker (1997) afirmam que a desnutrição em diferentes etapas da gestação pode ter como consequências alterações estruturais e fisiológicas irreversíveis, atraso no crescimento embrionário, diminuição do peso ao nascimento, além da ocorrência de diabetes, hipertensão e outras doenças na fase adulta.

A manifestação da subnutrição na República de Moçambique, de acordo com publicação oficial ${ }^{1}$, é responsável por um terço das mortes de crianças com idade inferior a cinco anos, e é a responsável por interferir no processo de crescimento durante os primeiros anos de vida, determinando uma condição conhecida como nanismo.

\footnotetext{
${ }^{1}$ República de Moçambique. 2010. Plano de ação multisetorial para a redução da desnutrição crônica em Moçambique 2011-2014 (2020). 111 paginas
} 
Como a desnutrição crônica é reconhecida como sendo o melhor indicador da qualidade do desenvolvimento humano, durante a Cúpula Mundial da Alimentação, em Roma no ano de 1996, as autoridades de Moçambique se comprometeram em reduzir, até 2015, a 50\% o número de pessoas desnutridas, um compromisso que), vem sendo concluído com relativo sucesso, devido aos problemas sociais que o País enfrenta (WHO, 2010).

Os efeitos da subnutrição têm sido analisados em diferentes órgãos e tecidos em pesquisas envolvendo ratos jovens submetidos à desnutrição pré e pós-natal, principalmente em relação à escassez proteica.

No sistema nervoso, foram verificados efeitos deletérios da desnutrição principalmente em componentes centrais - SNC (CORDERO, 1986; MORGANE, 1993; GONÇALVES, 2001; MORGANE, 2002; BOLINA-MATOS; 2012) sendo constatada diminuição significativa no peso do encéfalo (CORDERO et al., 1986), além de redução da espessura cortical e das áreas dos neurônios corticais e nitrérgicos (BOLINA-MATOS, 2012).

Em relação aos efeitos da desnutrição na parte periférica do sistema nervoso (SNP), poucos autores realizaram efetivamente pesquisas morfológicas nos diferentes tipos de nervos constituintes do organismo. Assim, Shrader e Zeman (1973) afirmam que em animais submetidos à desnutrição, a perda de peso e a dificuldade em alcançar o peso ideal com o desenvolvimento, determina modificações sobre os nervos em geral. Hedley-Whyte e Meuser (1971) analisaram o nervo isquiático de ratos e concluíram que a desnutrição pós-natal provoca alterações no crescimento circunferencial do axônio e no desenvolvimento da bainha de mielina. Para Sima et al. (1971) há uma diminuição no aumento do diâmetro das fibras nervosas, apontando provável diminuição no processo de mielinização, bem como alteração na permeabilidade da barreira do perineuro,

Em nervos cranianos, a subnutrição proteica promoveu uma diminuição no diâmetro dos axônios do nervo óptico (SIMA; SOURANDER, 1974), um atraso no desenvolvimento de fibras mielínicas do nervo alveolar inferior (BINOTTI, 2003) e diminuição na área dos corpos celulares dos neurônios constituintes do nervo trigêmeo (SIMÕES et al., 2009).

Pelo exposto, particularmente na parte periférica do sistema nervoso (SNP), os efeitos da desnutrição ainda é tema a ser explorado, quer seja em nervos espinais, cranianos ou autônomos. Desta forma, o presente trabalho visa contribuir 
para esse importante assunto, que ainda permanece como um problema de saúde pública, mormente em países subdesenvolvidos ou em vias de desenvolvimento. 
REVISÃO DE LITERATURA 


\section{REVISÃO DE LITERATURA}

Este capítulo dedica-se à descrição da literatura a partir de um levantamento bibliográfico detalhado sobre os assuntos envolvidos no estudo, sendo subdividido em tópicos.

\subsection{SUBNUTRIÇÃO: TERMINOLOGIA E CONCEITOS}

Quando realizada a busca pelo significado do termo "desnutrição", o dicionário Aurélio, escrito por Ferreira (2010) o conceitua como nutrição insuficiente ou nula. Quanto se refere ao termo "subnutrição", remete-se ao estado de nutrição insuficiente de um indivíduo e não nutrição nula. Já quando o termo empregado é má nutrição remete-se a ideia de alimentação inadequada e ineficiente em relação aos componentes nutricionais.

A literatura traz discussões pouco consensuais sobre essa terminologia. Morgane et al. (2002) define o termo subnutrição (undernutrition) a desnutrição energética, ou seja, uma alimentação incapaz de gerar energia suficiente para o desenvolvimento de uma pessoa, havendo uma defasagem geral de nutrientes. Já quando se fala de má nutrição (malnutrition) relaciona-se a um desequilíbrio de nutrientes nas refeições, nem sempre relacionada a escassez, podendo também indicar excesso. Monteiro (1995) já afirma que o termo desnutrição abrange todo e qualquer estado de deficiência quantitativa ou qualitativa, não diferenciando aquele indivíduo que se alimenta de forma errada daquele indivíduo que ingere pouca quantidade de nutrientes.

Existe ainda, segundo a FAO (2012), a inadequação alimentar, que quando tem sua prevalência comparada a prevalência de subnutrição, também inclui indivíduos com um déficit de fornecimento de energia pelos alimentos, ou seja, que não seriam consideradas subnutridas pela falta de nutrientes, mas que pode se tornar parte deste grupo quando se realiza o intenso esforço físico durante seu trabalho. Em alguns países, a diferença entre a prevalência de desnutrição e a prevalência de inadequação alimentar parece significativa, mostrando que uma parte 
considerável da população está sofrendo de ingestão inadequada de alimentos, apesar de subnutrição crônica não ser generalizada.

Há décadas a expressão "subnutrido" é capaz de englobar diversos termos que envolvem deficiência nutricionais. Em1986, Nóbrega já descrevia como sinônimos: kwashiorkor, marasmo, síndrome subnutricional aguda, despigmentação, pelagra infantil, edema de amido, má nutrição maligna, marasmo do desmame, caquexia edematosa, entre outros que descrevem a subnutrição de acordo com seus efeitos, sinais e sintomas.

Sendo esta uma abordagem complexa em que diferentes repercussões ocorrem simultaneamente, optou-se neste estudo pela utilização do termo subnutrição para designar a deficiência proteica.

\subsection{SUBNUTRIÇÃO NO MUNDO E A DIETA PADRÃO DE MOÇAMBIQUE}

A subnutrição é um problema de saúde pública, indicado como um marcador de pobreza vigente, que acomete consideravelmente crianças em áreas subdesenvolvidas do mundo (UNCF, 2015). Entre os anos de 2011 e 2014, alguns países tiveram prevalência de desnutrição superior ou igual a $35 \%$ da população total, e estão entre eles: Angola, Etiópia, Moçambique, República Democrática do Congo, República Centro-Africana, Chad, Zâmbia, todos localizados no continente africano. Segundo o Instituto Nacional de Estatística, Moçambique é um país da África Sub-Sahariana que em 2015 está composto por aproximadamente 25 milhões e meio de habitantes e esta situado no sudoeste africano (Instituto Nacional de Estatística, 2015) (Figura 1).

Na década de 90, de acordo com Julien et al. (1995), a subnutrição ocupava o quarto lugar no motivo de internações no Departamento de Pediatria do Hospital Central capital do país, Maputo, depois de doenças como a malária, diarreia e infecção respiratória. Os autores observam uma alta incidência de subnutrição grave, fazendo com que o país tivesse uma das maiores taxas de mortalidade, chegando a $20 \%$. 
Em 2010, a manifestação da subnutrição crônica na República de Moçambique de acordo com publicação oficial ${ }^{2}$, foi responsável por um terço das mortes de crianças com idade inferior a cinco anos, e quando não chegam ao óbito, deixa consequências irreversíveis como a baixa estatura, a menor capacidade física produtiva, redução da função cognitiva que leva a um menor rendimento escolar, e riscos elevados de acometimento por doenças como a diabetes e a obesidade (BLACK et al., 2008).

As medidas antropométricas, de acordo com a FAO (2012), são elementos importantes e fazem parte de um conjunto de indicadores de segurança alimentar. Elas passam informações sobre as consequências mais dramáticas e de longa duração de desnutrição crônica e aguda. Essas medidas em crianças menores de cinco anos de idade podem estimar o estado nutricional de uma população, sendo o nanismo possível resultante de uma nutrição inadequada prolongada e / ou infecções repetidas. Entre 2005 e 2011, um a cada quatro países africanos relataram uma taxa de desnutrição de pelo menos $40 \%$, o que é considerado pela Organização Mundial de Saúde (OMS) uma prevalência muito alta. Os países com altas taxas de baixa estatura e baixo peso estão espalhados por toda a África, sendo o continente que mais se destaca (FAO, 2012).

A disponibilidade de alimentos numa determinada região nem sempre é sinônimo de segurança alimentar.

Nas últimas décadas, as tendências na produção de alimentos foram positivas de maneira geral em todo o mundo. No entanto, as taxas de crescimento na África tem sido menor nos últimos 20 anos, com exceções de algumas regiões. Em média, a produção agrícola na África tem aumentado a um pouco menos de $1 \%$ ao ano, em comparação com cerca de $2 \%$ nos países em desenvolvimento em geral. Dicas sobre segurança alimentar podem ser percebidas através de indicadores. O gasto energético da população em geral aumentou nos últimos 20 anos e quando refere-se a participação da energia fornecida por cereais, raízes e tubérculos, diminuiu $51 \%$ em 2007-2009 e a quantidade de proteína utilizada por pessoa, por dia aumentou em $13 \%$ a nível mundial no mesmo período (FAO, 2012).

\footnotetext{
${ }^{2}$ República de Moçambique. 2010. Plano de ação multisetorial para a redução da desnutrição crônica em Moçambique 2011-2014 (2020). 111 paginas
} 
Figura 1 - Localização de Moçambique no Continente Africano

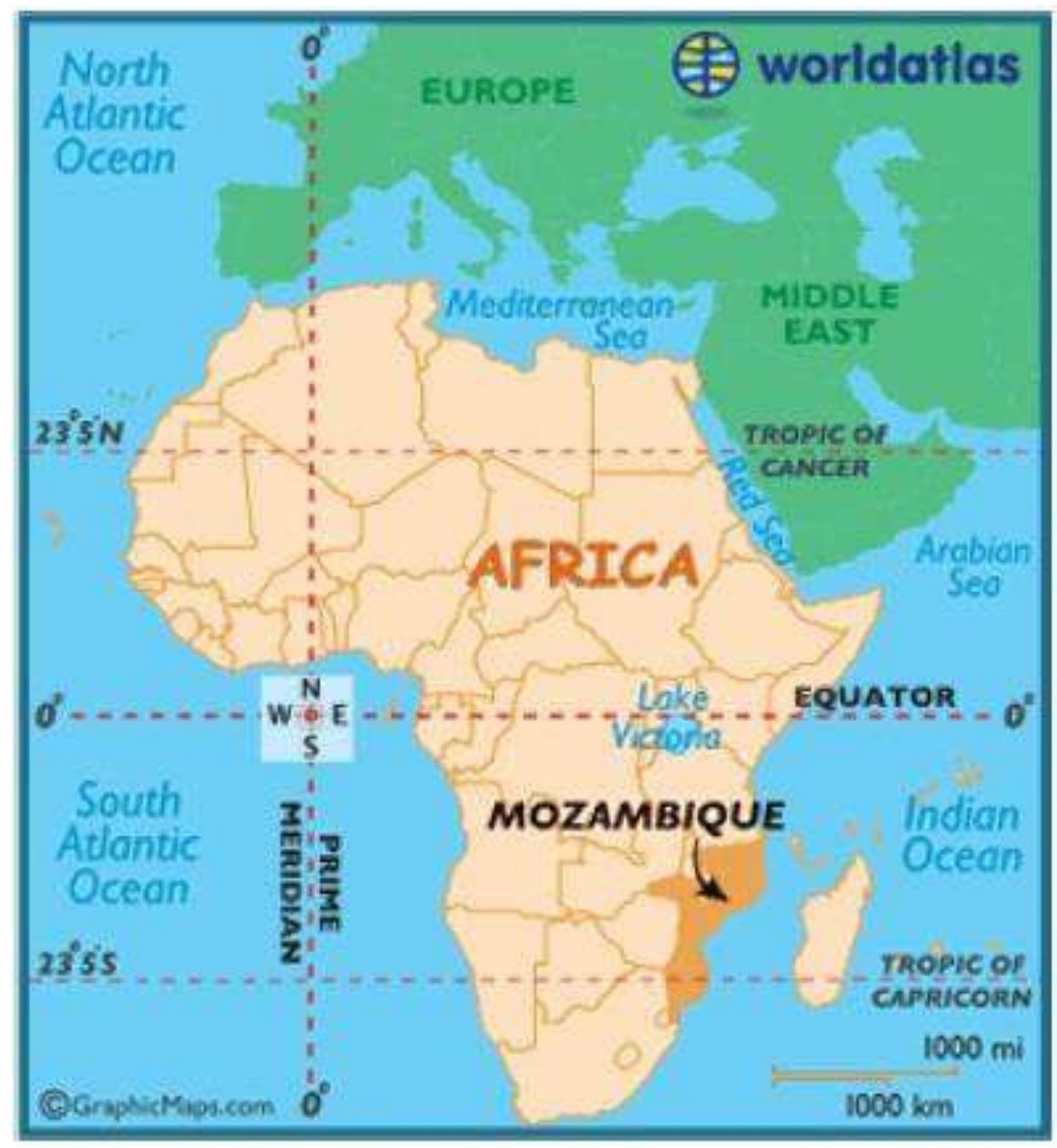

Fonte: (WORLD ATLAS, 2015).

Legenda: Moçambique se localiza no sudoeste africano.

Enquanto a tendência de outras regiões é reduzir a oferta energética basicamente vegetal, a África mostra tendência em manter esse indicador, como mostra a figura 2. A participação dos produtos pecuários no fornecimento de proteína vem crescendo a nível global, com os países em desenvolvimento fazendo grandes progressos. Na maioria dos países e regiões, a alta disponibilidade de alimentos está associada a taxas relativamente baixas de subnutrição. No entanto, a alta disponibilidade de alimentos nem sempre garante a segurança alimentar elevado. No Egito, por exemplo, o nanismo afeta $31 \%$ das crianças menores de cinco anos de idade, enquanto a adequação do fornecimento da dieta é $45 \%$ maior do que a necessidade média (FAO, 2012).

Situações semelhantes acontecem em Benin, Malawi, Níger e Cazaquistão onde a baixa estatura de sua população indica problemas nutricionais, afetando 20 a 
45\% da população. Estes dados podem indicar a presença de grupos específicos da população que sofrem de subnutrição, apesar de abundantes fontes de alimento de origem vegetal (FAO, 2012).

Figura 2 - Representação gráfica do suprimento energético derivada de cereais, raízes e tubérculos (1990-1992 e 2007-2009)

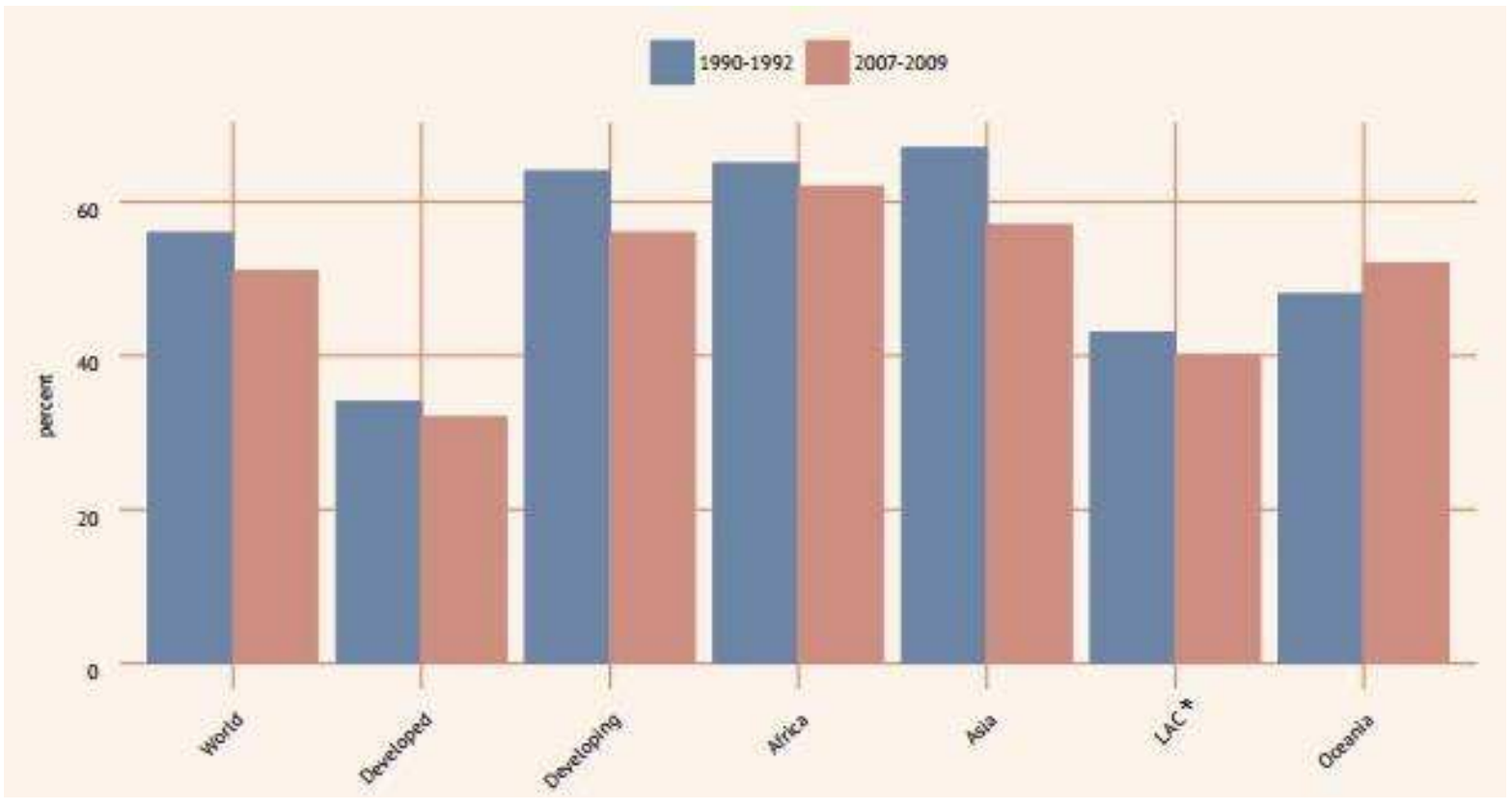

Fonte: (FAO, 2012).

Legenda: O continente Africano se destaca entre os anos de 2007-2009. *LAC: América Latina e Caribe.

No Brasil, até 2011 a subnutrição ainda era considerada um problema grave de saúde pública, sendo responsável por uma porcentagem alta na morte de crianças no mundo, dado que pode ser ilustrado em um mapa da fome, publicado pela WFP (2014) - World Food Programme, que coloca o Brasil em um índice de 5 - 9\% em 2011, reduzindo para $>5 \%$ em 2014. Moçambique apesar de que ter também ter reduzido esta porcentagem nos anos avaliados, ainda há grande preocupação em relação ao estado nutricional de seus habitantes, estando em uma média de 2534,9\% da população (WFP, 2014) (Figura 3).

A dieta básica de oferecida a população de Moçambique, tem como principal fonte de proteínas o amendoim, além de outros componentes como farinha de milho, couve liofilizada. O amendoim pode variar seu conteúdo de proteína de 21,0 a $36,4 \%$ (WOODROOF, 1983). 
Segundo Hiane et al. (2006), a digestibilidade determina a qualidade proteica da dieta, medindo a fração de proteínas hidrolisadas por enzimas digestivas e absorvidas pelo organismo na forma de aminoácidos, ou de outro composto nitrogenado. Macedo e Damico (2000) descrevem que proteínas que possuem ligações peptídicas que não são hidrolisadas pelo processo digestivo, são excretadas nas fezes ou sofrem transformações no intestino grosso. Sendo assim, uma significativa parte das proteínas de origem animal proporcionam uma boa absorção de aminoácidos, como especificamente a caseína, que apresenta teor proteico de 81,57\% (PIRES et al., 2006), e digestibilidade de cerca de 96\% (SGARBIERI, 1987). As proteínas de origem vegetal são mais resistentes à ação de enzimas, havendo um prejuízo dessa característica tão importante (CARIAS et al.,1995).

\subsection{TIPOS DE SUBNUTRIÇÃO}

A subnutrição crônica, ainda conhecida pelo termo "desnutrição crônica" (DC), de maneira geral, é determinada pela baixa estatura em relação à idade, diferente da "desnutrição aguda" (DA), definida como baixo peso em relação à altura. A DC é ocasionada pela DA não tratada no tempo entre a concepção do indivíduo e os primeiros dois anos de vida, fase crítica do desenvolvimento, deixando sequelas irreversíveis após os dois anos de idade. A DC, portanto, é causada por desnutrição materna, durante a lactação e no período de dois anos pós-natal. A DA é passível de ser manifestada em qualquer fase da vida, podendo haver recuperação (LI et al., 2003). 
Figura 3 - Mapa da fome

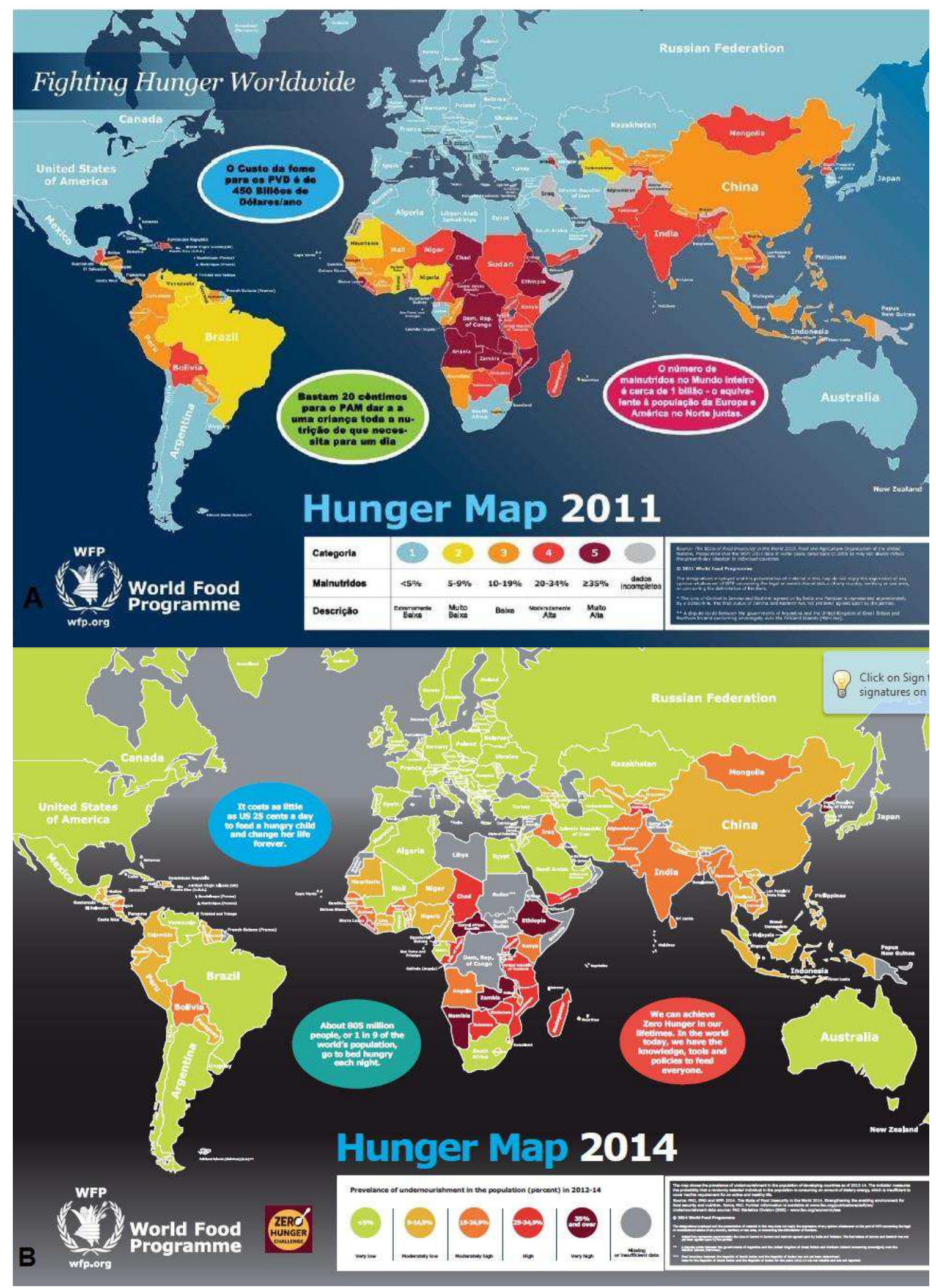

Fonte: (WFP, 2011, 2014).

Legenda: Diferenças do Índice de subnutrição no mundo em 2014 comparado a 2011. 
De acordo com Martins (2008), existem indicadores de desnutrição que são:

1- DC: É considerada por vários autores como a mais significativa e exerce influência sobre o crescimento da criança. Reflete a situação alimentar da família e da sociedade e é medida pela relação altura/idade (com desvio padrão menor do que 2).

2. DA: Revela situações de crise alimentar, determinada pelo emagrecimento da criança e não é pouco expressiva em Moçambique. Sua medida é calculada pela relação Peso/Altura (com desvio padrão menor do que 2).

3. Peso para a idade: Este é um indicador misto de DC e DA, não mostrando muita especificidade, porém é o que tem relevância nas Metas dos Objetivos do Milênio em Moçambique, dado relevante na região. Sua interpretação é mais complexa.

\subsubsection{Outros tipos de subnutrição}

Um dos tipos de subnutrição é a desnutrição energético-proteica (DEP) que tem maior incidência em crianças em fase de amamentação e com menos de 5 anos de idade (GIBSON et al., 2003). É uma síndrome que abrange diversos sintomas, cada um relacionado especificamente a um nutriente (proteínas, iodo ou cálcio). A DEP é determinada pela existência de um desequilíbrio celular entre o fornecimento de nutrientes e energia, e a necessidade que o organismo tem para garantir 0 crescimento e a manutenção de funções vitais (JAHOOR et al., 2008).

Existe também a desnutrição proteico-calórica (DPC) que subdivide-se em três formas: DPC seca, na qual o indivíduo aparenta magreza e desidratação; DPC molhada, também chamada kwashiorkor, em que o indivíduo apresenta inchaço decorrente da retenção hídrica; e a DPC intermediária que é consequente de um quadro típico de "fome" e é também chamada de marasmo (NÓBREGA, 1986).

No marasmo a criança ingere uma quantidade de alimento pequena, apresentando uma magreza extrema proveniente da perda de massa muscular e gordura, e estando debilitado, também está susceptível a qualquer tipo de infecção (NÓBREGA, 1986). 
O nome kwashiorkor, significa "mal da primeira criança", porém só se aplica ao primeiro filho após o nascimento do segundo filho, pois entende-se que o primeiro foi deixado de lado ao ser desmamado para dar lugar ao segundo. Fisiologicamente, este estado de subnutrição em que há carência proteica é mais relevante que a deficiência calórica, pois acarreta a redução de proteínas plasmáticas, reduzindo também a pressão coloidosmótica e por fim, o fluxo osmótico através das paredes dos capilares, justificando a retenção de fluídos (edema generalizado), doenças de pele e despigmentação do cabelo (VINCENT; RADERMECKER,1959) (Figura 4).

Em um estágio intermediário, há a DPC denominado kwashiorkor marasmático. Crianças com esse tipo de subnutrição retêm fluidos em quantidade menor, mas possuem mais gordura corporal que aquelas exclusivamente marasmáticas (RACELA et al., 1966; JAHOOR et al., 2008).

De acordo com Jahoor et al. (2008), a carência proteica exerce influência no desenvolvimento corporal, na imunidade, na cicatrização e produção de enzimas e hormônios.

Figura 4 - Crianças com DPC tipo marasmo e kwashiorkor
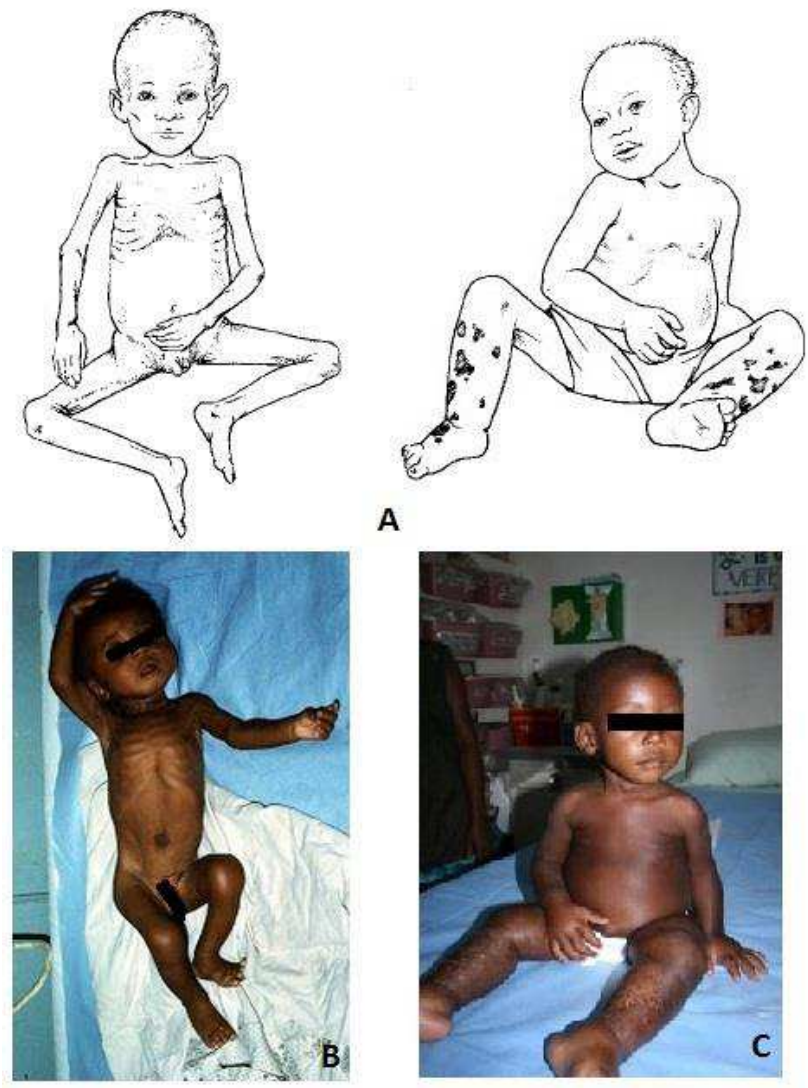

A

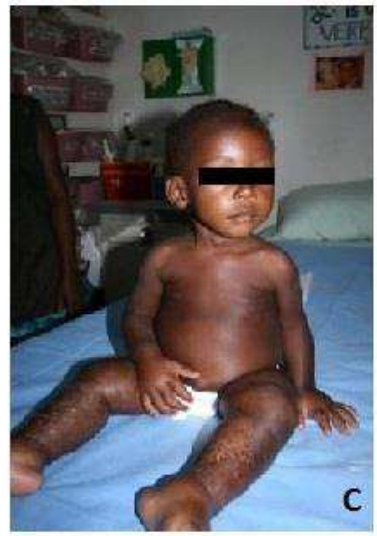

Fonte A: www.ichrc.org ([200-?]).

Fonte B e C: www.realhopeforhaiti.org ([200-?]).

Legenda: Diferentes manifestações da DPC marasmática e kwashiorkor. 


\subsection{EVIDÊNCIAS SOBRE A INFLUÊNCIA DA SUBNUTRIÇÃO NO SISTEMA NERVOSO}

A maturação e o desenvolvimento do sistema nervoso dependem fundamentalmente de três fatores: potencial energético, estímulo ambiental e de uma nutrição adequada (MORGANE et al., 1993). O terceiro fator, quando não comtemplado, pode determinar alteração no crescimento e elaboração de circuitos neuronais (MORGANE et al., 2002).

Alguns autores estudaram possíveis alterações decorrentes da subnutrição. Parada-Simão et al. (2011) analisaram a musculatura estriada esquelética e perceberam redução da área transversal do gastrocnêmio. Spanheimer et al. (1991), avaliando as articulações de animais submetidos a restrição alimentar parcial, observaram diminuição da síntese da matriz de colágeno da cartilagem articular.

Foram vistas ainda, modificações estruturais e ultra-estruturais no complexo polpa-dentina e nos componentes do periodonto de dentes molares em ratos desnutridos (GONÇALVES et al., 2009).

Sima e Sourander (1974) calcularam o diâmetro das fibras mielínicas dos nervos ópticos de ratos desnutridos comparando-os com animais nutridos. Concluíram que aos 20 dias de vida extra-uterina, a quantidade de fibras com diâmetro menor que $0,75 \mu \mathrm{m}$ era maior em ratos desnutridos do que em ratos nutridos, porém, ao completarem 90 dias de vida extra-uterina, essa diferença era menor. Aos 180 dias, a comparação foi realizada entre animais nutridos, desnutridos e renutridos, havendo diminuição do diâmetro das fibras de animais desnutridos, demonstrando irreversibilidade. O resultado foi relacionado pelos autores a uma redução da bainha de mielina.

Bedi e Warren (1983) buscaram analisar o nervo óptico de ratos desnutridos, com restrição alimentar a partir do $18^{\circ}$ dia de gestação até o $100^{\circ}$ dia de vida extrauterina, e observaram que no $25^{\circ}$ dia de vida extra-uterina, ocorreu uma diminuição de $36 \%$ no número total de fibras do nervo destes animais, sendo a maior parte das fibras, com diâmetro médio reduzido para a idade.

Já Conradi et al. (1989), estudaram o diâmetro, quantidade e mielinização de axônios do nervo óptico de ratos com restrição alimentar proteica nos períodos pré e pós-natal. Os animais foram avaliados aos 5, 12, 20 e 30 dias de vida extra-uterina e 
perceberam que quanto ao número total de axônios, não houve significância quando comparados animais nutridos e desnutridos, porém foi visto uma redução do número total de axônios maiores que $0,52 \mu \mathrm{m}$, assim como o número total de fibras nervosas mielínicas.

\subsection{A PARTE PERIFÉRICA DO SISTEMA NERVOSO E O NERVO ISQUIÁTICO}

O tecido nervoso é composto por três tipos de células: neurônios (células nervosas), lemócitos e neuroglia. Tratando-se apenas do neurônio, pode-se afirmar que é o componente essencial do sistema nervoso, tanto em relação a estrutura quando a função, e tem a competência de responder a estímulos, originando e conduzindo sinais elétricos. Cada neurônio é constituído por um corpo celular e um ou mais prolongamentos contendo citoplasma. O prolongamento de vários neurônios unidos entre si por bainhas de tecido conjuntivo constituem um nervo. Cada fibra nervosa é envolvida por uma fina bainha de tecido conjuntivo chamado endoneuro e os prolongamentos dos neurônios são separados em conjuntos por outra bainha de tecido conjuntivo, o perineuro. Cada conjunto de fibras nervosas envolvidas pelo perineuro é chamado de fascículo. Por fim, vários fascículos envoltos por bainha de tecido conjuntivo é chamado epineuro (SPENCE, 1991).

Os nervos e gânglios formam o sistema nervoso periférico (SNP) e estas estruturas estão localizadas fora do sistema nervoso central. Os nervos unem ao sistema nervoso central os receptores que ficam localizados em todo o corpo, e os gânglios são grupos de corpos de neurônios associados aos nervos. Ao SNP pertencem 12 pares de nervos cranianos originados no cérebro e tronco encefálico, e 31 pares de nervos espinhais que saem da medula espinhal, deixam o canal vertebral através de forames intervertebrais. Os pares de nervos espinhais são 8 cervicais, 12 torácicos, 5 lombares, 5 sacrais e 1 coccígeo. Além disso, o SNP pode ser dividido funcionalmente em um componente aferente (sensitivo) e um componente eferente (motor) (GRAY, 1988).

De acordo com Martini, Timmons, Tallitsch (2009), nervo isquiático é o maior nervo do corpo e é formado pelo principal ramo do plexo sacral, sendo formado por dois nervos envoltos por uma mesma bainha de tecido conjuntivo: o nervo fibular 
comum e o nervo tibial, ilustrada na figura 5. Ao sair da pelve é conduzido inferiormente pela face posterior da coxa, inervando os músculos e apele da região.

Figura 5 - Representação da localização do nervo isquiático

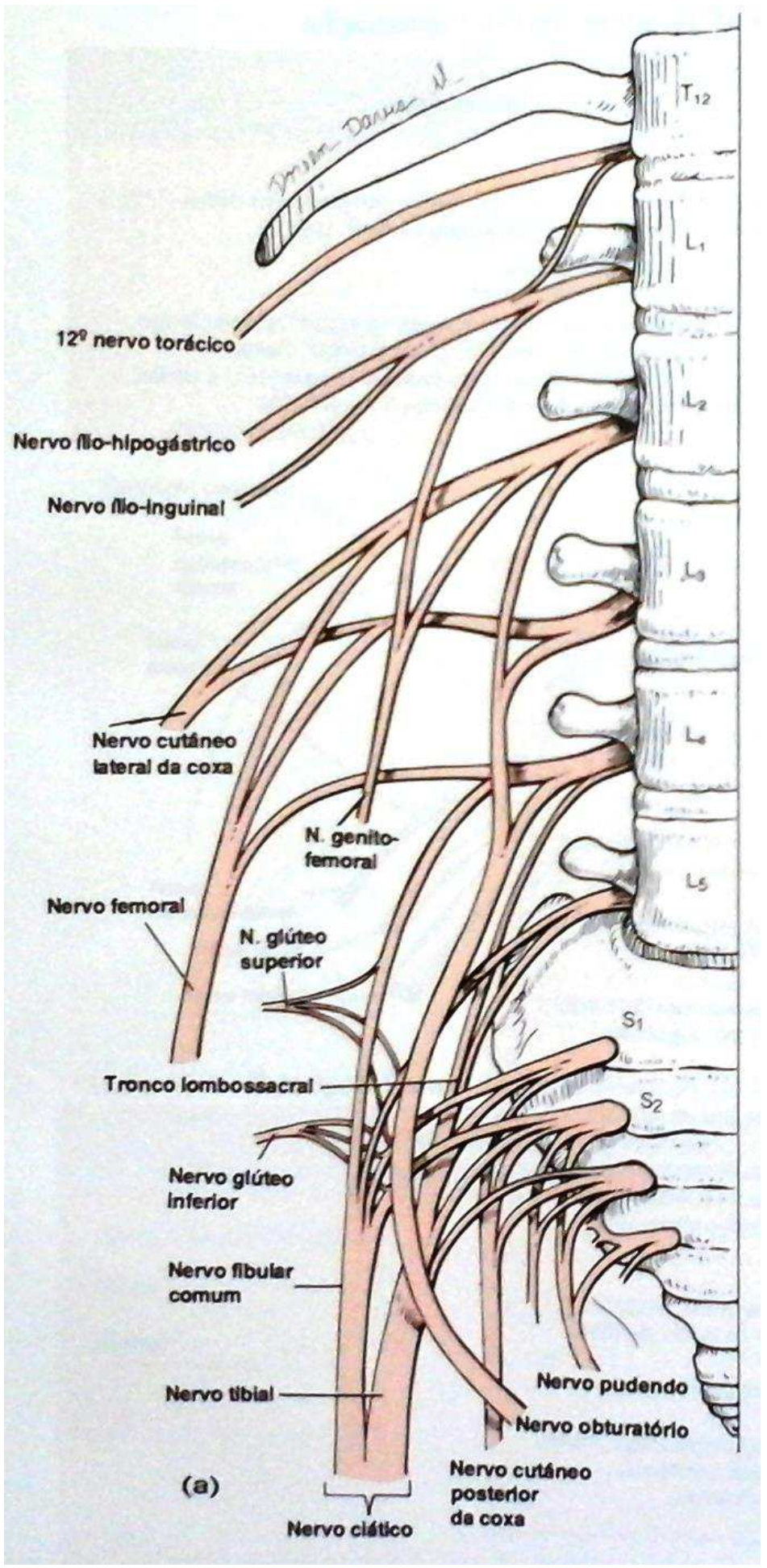

Fonte: (SPENCE, 1991).

Legenda: Observar o nervo fibular comum e o nervo tibial formando o nervo isquiático. 
OBJETIVOS 


\section{OBJETIVOS}

Ao considerar o panorama advindo dos efeitos da subnutrição sobre órgãos e tecidos vitais para o desenvolvimento humano, torna-se necessário elucidar as reais repercussões causadas sobre o sistema nervoso periférico, investigando em sua morfologia possíveis alterações.

\subsection{OBJETIVO GERAL}

Investigar, no tecido nervoso periférico de ratos Wistar, as possíveis repercussões morfológicas dos efeitos da subnutrição proteica, comparando com animais submetidos à dieta padrão de Moçambique (hipoproteica) e com animais que receberam nutrição proteica balanceada.

\subsection{OBJETIVOS ESPECÍFICOS}

Sendo a desnutrição um fator que pode modificar o desenvolvimento e estrutura de nervos em geral, objetiva-se analisar nos segmento do nervo isquiático de ratos submetidos à desnutrição proteica ( $5 \%$ caseína) e à dieta de Moçambique:

a) A estrutura e a ultra-estrutura dos componentes do nervo;

b) A área seccional transversa do nervo;

c) A densidade das fibras nervosas mielínicas;

d) O número total estimado de fibras nervosas mielínicas;

e) A área seccional transversa dos axônios, das bainhas de mielina e das fibras nervosas mielínicas. 
MATERIAIS E MÉTODOS 


\section{MATERIAIS E MÉTODOS}

Este tópico compreende a descrição detalhada da metodologia do estudo, de acordo com a cronologia dos acontecimentos. A presente pesquisa foi desenvolvida no Departamento de Anatomia do Instituto de Ciências Biomédicas III da Universidade de São Paulo (ICBIII-USP).

\subsection{GRUPOS EXPERIMENTAIS}

Foram utilizados Ratos Wistar (Rattus norvegicus) machos e fêmeas, com peso entre 280 e 320 gramas, obtidos do Biotério Central do Instituto de Ciências Biomédicas da Universidade de São Paulo (ICB/USP) e acondicionados em gaiolas de polipropileno, dispostos em estante vertical, no Biotério do Departamento de Anatomia do mesmo Instituto. Os animais foram mantidos em salas climatizadas com temperatura controlada entre 23 e $25^{\circ} \mathrm{C}$, e em ciclo de claro/escuro de 12 horas.

Tendo como base a dieta AIN-93G (REEVES, 1993) foram preparadas, por um laboratório bioquímico especializado ${ }^{3}$, as seguintes dietas: uma contendo $5 \%$ de caseína (S); outra contendo $20 \%$ de caseína (N), e uma terceira, com componentes que simularam aquela fornecida à população de Moçambique (M), cujo conteúdo proteico vegetal é extraído do amendoim.

Depois de ambientados no biotério, os animais foram acasalados e permaneceram 1 macho para 2 fêmeas em uma mesma gaiola, por um período de 10 dias (Sistema Poligâmico), sendo oferecidas a grupos distintos sem restrições de água, as dietas N, S e M. Decorrido o período de acasalamento, durante a gestação, as fêmeas foram separadas em gaiolas individuais de acordo com as respectivas dietas, e mantidas durante o período de amamentação juntamente com os filhotes. Para evitar possíveis diferenças no número de filhotes, foi padronizado um número mínimo de 4 e número máximo de 8 animais por ninhada. Para isso, foram desprezadas aquelas com menos de 4 filhotes; os excedentes de ninhadas com

\footnotetext{
${ }^{3}$ Rhoster Indústria e Comércio Ltda, Araçoiaba da Serra, SP, Brasil.
} 
mais de 8 filhotes; ninhadas cujas mães alimentaram-se dos filhotes, e os filhotes do sexo feminino. Ao completarem 21 dias de vida extra-uterina, época determinada para o desmame, os filhotes de cada grupo $(\mathrm{N}, \mathrm{S}, \mathrm{M})$ foram preparados para a coleta dos nervos isquiáticos, posteriormente submetidos às diferentes técnicas.

O fluxograma da figura 6 ilustra os procedimentos para a obtenção dos animais de todos os grupos experimentais (N, S e M).

Figura 6 - Fluxograma do período experimental - 2013

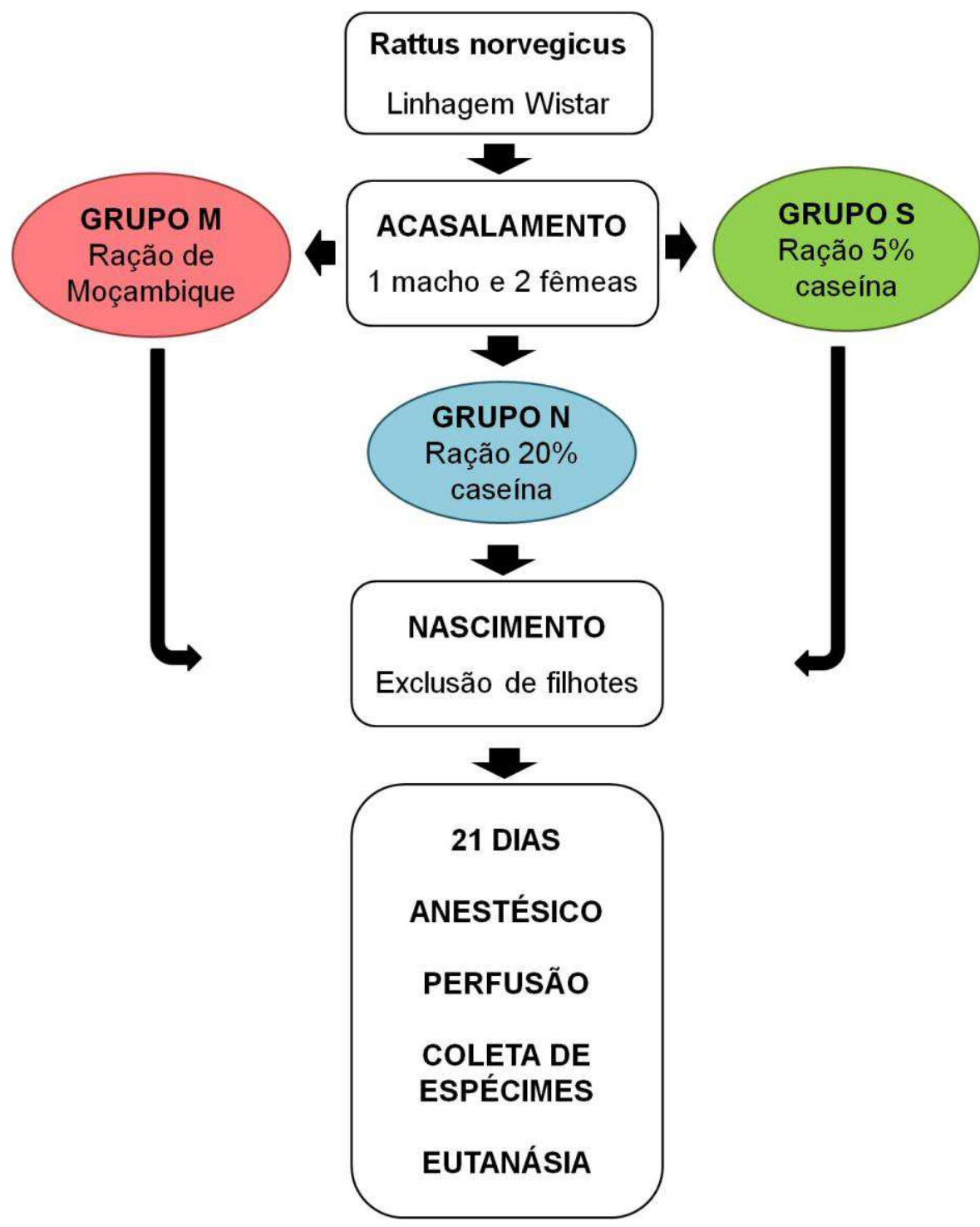

Fonte: (MENDONÇA L. P., 2015).

Legenda: Representação esquemática da obtenção de animais de todos os grupos experimentais ( $N$, $\mathrm{S}$ e $\mathrm{M}$ ). 


\subsection{MICROSCOPIA ELETRÔNICA DE VARREDURA (MEV)}

Após anestesiados com injeção subcutânea de um coquetel de anestésicos contendo xilazina (10 mg/ $\mathrm{Kg}$ de peso animal) e cetamina (50mg/Kg de peso animal), foi realizado em três animais de cada grupo $(\mathrm{N}, \mathrm{S}, \mathrm{M})$ uma incisão longitudinal da parede anterior da caixa torácica, a fim de se expor o coração. Em seguida, foi realizado a partir do ventrículo esquerdo, uma perfusão de solução de Karnovsky modificada $(2 \%$ de paraformoldeído, $25 \%$ de glutaraldeído e solução tampão cacodilato a $1 \mathrm{M}, \mathrm{pH} 7,4)$.

A parte medial do membro posterior esquerdo de todos os animais foi então dissecada afastando-se os tecidos moles até a visualização do nervo, de onde foi retirado um segmento de aproximadamente $1 \mathrm{~cm}$, proximal à sua origem. Os segmentos foram imersos na mesma solução fixadora por um período de 24 horas a $4^{\circ} \mathrm{C}$, lavados em tampão fosfato de sódio (PBS - 0,1M pH 7,3) e processados de acordo com as técnicas descritas a seguir.

\subsubsection{Técnica do Hidróxido de Sódio $(\mathrm{NaOH})$}

Realizada de acordo com Ohtani et al. (1988), essa técnica de maceração celular foi utilizada para demonstrar a organização tridimensional das fibrilas colágenas dos envoltórios conjuntivos constituintes do nervo isquiático (epi, peri e endoneuro) em três fragmentos de aproximadamente $0,5 \mathrm{~cm}$ de cada nervo isquiático de todos os grupos ( $N, S$ e $M$ ). Assim, os mesmos foram imersos em solução aquosa de hidróxido de sódio $(\mathrm{NaOH})$ a $10 \%$ por 3 dias à temperatura ambiente. Após esse tratamento, os espécimes foram lavados em água destilada por 24 horas a $4^{\circ} \mathrm{C}$, pós-fixados em tetróxido de ósmio $(\mathrm{OsO} 4)$ a $1 \%$ por 2 horas a $4^{\circ} \mathrm{C}$, lavados em água destilada e desidratados em série crescente de álcoois, a partir do álcool $70 \%$ até o absoluto. 


\subsubsection{Técnica do Ácido Clorídrico (HCl)}

Para a preparação dos componentes do tecido conjuntivo, três fragmentos de aproximadamente $0,5 \mathrm{~cm}$ de cada nervo isquiático de todos os grupos ( $N$, S e $M)$. foram submetidos à técnica de digestão do material extracelular preconizada por Evan et al. (1976). Desta forma, após a lavagem em PBS, foram imersos em solução de ácido clorídrico $(\mathrm{HCl}) 8 \mathrm{~N}$ a $60^{\circ} \mathrm{C}$ durante 50 minutos. Ao final desse período, os espécimes foram lavados em PBS, pós-fixados em tetróxido de ósmio $\left(\mathrm{OsO}_{4}\right)$ a $1 \%$ por 2 horas a $4^{\circ} \mathrm{C}$, lavados novamente no mesmo tampão e desidratados em série crescente de álcoois (do $70 \%$ ao absoluto).

Após a desidratação, todos os espécimes utilizados nos itens 3.2.1 e 3.2.2 foram secos utilizando-se dióxido de carbono (CO2) líquido ${ }^{4}$, montados em bases metálicas apropriadas, cobertos com íons de ouro ${ }^{5}$, e examinados e fotografados em microscópio eletrônico de varredura ${ }^{6}$ do Departamento de Anatomia da Faculdade de Medicina Veterinária e Zootecnia da Universidade de São Paulo (VClAnatomia/FMVZ-USP).

\subsection{MICROSCOPIA ELETRÔNICA DE TRANSMISSÃO (MET)}

Para esse procedimento, segmentos de aproximadamente $0,5 \mathrm{~cm}$ do nervo isquiático de cinco animais de cada grupo $(\mathrm{N}, \mathrm{S}, \mathrm{M})$ obtidos de acordo com o descrito no item 3.2, foram mantidos em uma solução fixadora (glutaraldeído a 2,5\%, por 4 horas a $4^{\circ} \mathrm{C}$ ), Após serem lavados em PBS, os segmentos foram pós-fixados durante 2 horas a $4{ }^{\circ} \mathrm{C}$ por imersão em solução de tetróxido de ósmio $\left(\mathrm{OsO}_{4}\right)$ a $2 \%$, lavados em PBS e mantidos em solução aquosa de acetato de uranila a 0,5\%, por um período de 12 horas à temperatura ambiente e local escuro. Em seguida, para que ocorresse a substituição da água do material por um fluido miscível tanto na água quanto na resina (óxido de propileno), os segmentos foram desidratados em

\footnotetext{
${ }^{4}$ Balzers SCD 030

${ }^{5}$ Balzers, SPD 040

${ }^{6}$ Jeol, JSM - 6100, do Centro de Microscopia Eletrônica do Instituto de Ciências Biomédicas da USP.
} 
série crescente de álcoois $(1 \mathrm{x}$ em álcool $70 \%, 80 \%, 90 \%, 95 \%$; $4 \mathrm{x}$ em álcool absoluto; 2x em óxido de propileno), permanecendo 15 minutos em cada banho.

Após a desidratação, os fragmentos permaneceram sob agitação em uma solução de resina e óxido de propileno na proporção de 1:1 por 4 horas, que foi trocada por resina pura (1x em um período de 18 horas e $1 \mathrm{x}$ durante 60 minutos). $\mathrm{A}$ inclusão dos fragmentos foi realizada em moldes retangulares preenchidos por resina e mantidos por 5 dias em estufa a $60^{\circ} \mathrm{C}$, para que ocorresse a polimerização dos blocos.

Em seguida, os blocos foram trimados e com o uso de ultramicrótomo, foram obtidos cortes semifinos de 300nm corados com azul de toluidina a 1\% para análise em microscopia de luz. Selecionada a área de interesse do fragmento, foram realizados cortes ultrafinos de $50 \mathrm{~nm}$ em três espécimes de cada grupo, coletados em telas de cobre de 200 "mesh" contrastados com solução aquosa de acetato de uranila a $4 \%$ por 3 minutos, lavados com água destilada, contrastados com solução aquosa de citrato de chumbo a $0,4 \%$ por 3 minutos e novamente lavados com água destilada. As telas foram analisadas em microscópio eletrônico de transmissão ${ }^{7}$ do Departamento de Anatomia da Faculdade de Medicina Veterinária e Zootecnia da Universidade de São Paulo (VCI-Anatomia/FMVZ-USP).

\subsection{MORFOMETRIA E ESTEREOLOGIA}

Para essas metodologias morfoquantitativas foram utilizados três cortes semifinos dos nervos isquiáticos de cada um dos cinco animais dos diferentes grupos (N, S, M) processados para a microscopia eletrônica de transmissão corados com azul de toluidina a $1 \%$ e montados entre lâmina e lamínula (Item 3.3).

\footnotetext{
${ }^{7}$ FEI Morgani 268 (D). USA.
} 


\subsubsection{Determinação da área seccional transversa do nervo isquiático (ASTn)}

Através de um microscópio com objetiva de 10x (Axioscope 40) munido de uma câmara (Axiocam) acoplada a um sistema computadorizado de captura e imagens (Axiovision Rel. 4.6, Carl Zeiss, Göttingen, Alemanha) a ASTn (em $\mathrm{mm}^{2}$ ) foi determinada em fotomicrografias de cada corte. Os valores, inicialmente obtidos em $\mu \mathrm{m}^{2}$ foram posteriormente convertidos em $\mathrm{mm}^{2}$ (Figura 7 ).

Figura 7 - Determinação da área seccional transversa do nervo isquiático (ASTn)

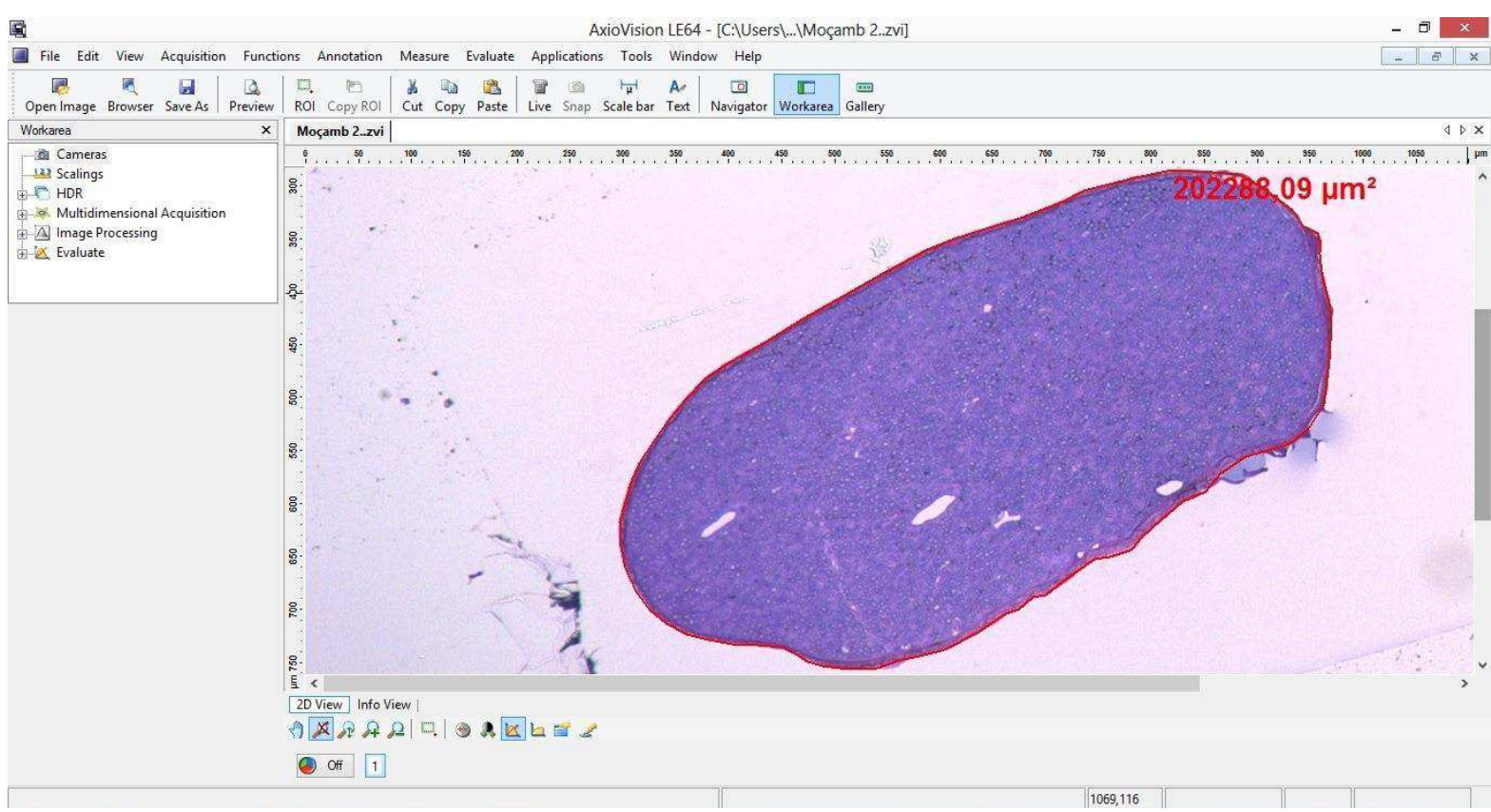

Fonte: (MENDONÇA, L. P., 2015).

Legenda: Demonstração de como é feita a medida de área seccional transversa de um nervo.

\subsubsection{Determinação da densidade e do número total estimado de fibras nervosas mielínicas no nervo isquiático}

Esses parâmetros foram determinados utilizando-se um modelo estereológico denominado "disector" bidimensional (db), descrito por Geuna et al. (1999), cujo princípio está associado a um esquema de amostragem aleatório e sistemático, com análise a partir do cálculo do coeficiente de erro (Figura 8). 
Figura 8 - Esquema ilustrativo do procedimento utilizado para a obtenção dos campos de amostragem ou dbs

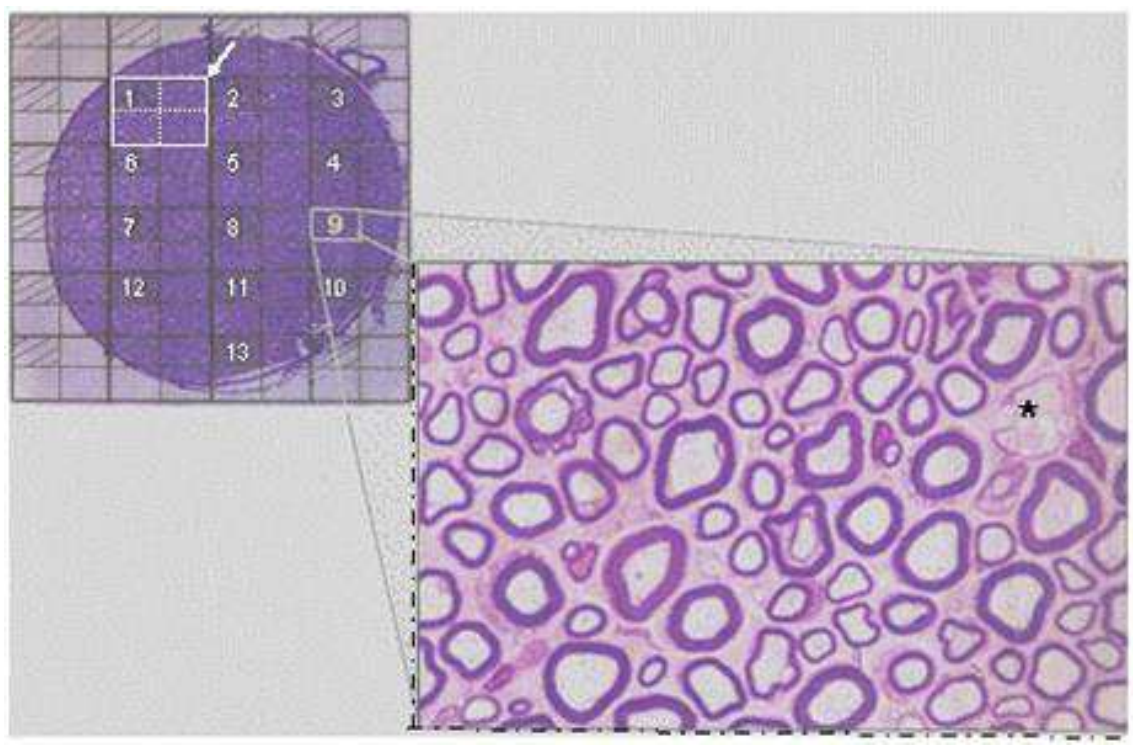

Fonte: (BINOTTI, 2003).

Legenda: Demonstração de como é feita a seleção dos dbs.

A metodologia constituiu-se a princípio, na visualização e posicionamento aleatório de um corte transversal semifino de cada nervo com pequeno aumento (30x), de forma que qualquer direção de observação tenha a mesma chance de ser selecionada. Após os cortes serem posicionados, foram obtidas fotomicrografias com aumento de 100x, os dbs foram obtidos de acordo com as seguintes etapas:

1 - a ASTn foi dividida de acordo com sua dimensão em um número variável de sub-áreas de tamanhos uniformes;

2 - cada sub-área foi dividida em quatro campos de amostragem ou dbs, também uniformes;

3 - em uma dessas sub-áreas, um db inicial (dbi) foi selecionado aleatoriamente, tendo como referência o topo do nervo;

4 - a partir do $\mathbf{d b i}$, foi passado sistematicamente para o $\mathbf{d b}$ correspondente às demais sub-áreas obtendo-se desta forma, a quantidade de dbs equivalente à quantidade de sub-áreas. Todos os dbs selecionados foram fotografados, mostrando nas fotomicrografias a área real de cada um deles.

Nas fotomicrografias dos dbs foi feita a contagem do número de fibras nervosas mielínicas, contando-se todas aquelas que tiveram seus topos posicionados em cada um dos dbs selecionados. O topo de cada fibra nervosa mielínica foi identificado como primeiro ponto de seu contorno que tocar o plano de observação definido (com uma direção norte-sul), independente da posição das 
partes remanescentes da fibra. Para aquelas fibras que tiveram seus topos posicionados exatamente em cima das margens do $\mathbf{d b}$, foram definidas duas margens de inclusão e duas de exclusão. Desta forma, o topo de uma fibra foi contado em apenas um $\mathbf{d b}$, podendo a fibra ser contada uma única vez.

A densidade numérica de fibras nervosas mielínicas por $\mathrm{mm}^{2}$ a partir de cada db (N'A) foi então, calculada pela seguinte fórmula:

$$
\text { N'A = Q'/A }
$$

em que Q' corresponde ao número de fibras nervosas mielínicas somadas em um determinado $\mathbf{d b}$ e $\mathbf{A}$, à área do $\mathbf{d b}\left(\mathrm{em} \mu \mathrm{m}^{2}\right)$.

O número total de fibras nervosas mielínicas a partir de cada $\mathbf{d b}\left(\mathbf{N}^{\prime}\right)$, foi calculado a partir da fórmula abaixo:

\section{$N^{\prime}=N^{\prime} A \times$ A [tot]}

em que $\mathbf{A}$ [tot] corresponde à área seccional transversa real do nervo, excluindo-se o epineuro. A densidade (NA) e o número total estimado final (N) de fibras nervosas mielínicas em cada nervo isquiático, foram determinados a partir do cálculo da média das estimativas obtidas em cada um dos dbs do respectivo nervo, usando as seguintes fórmulas:

$$
\mathbf{N A}=\boldsymbol{\Sigma} \mathbf{N}^{\prime} \mathrm{A} / \mathrm{n} \quad \mathrm{e} \quad \mathbf{N}=\boldsymbol{\Sigma} \mathbf{N}^{\prime} / \mathbf{n}
$$

em que $\mathbf{n}$ corresponde ao número de $\mathbf{d b s}$ selecionados e analisados em cada nervo.

Por fim, para que seja analisado o esquema de amostragem utilizado e consequentemente, a precisão das estimativas da densidade e da quantidade total de fibras nervosas mielínicas em cada nervo isquiático, foi devido o cálculo do coeficiente de erro (CE), aplicando-se para o número de fibras contado em cada $\mathbf{d b}$ (Q'), a seguinte fórmula:

$$
C E=1 / \sqrt{ } \Sigma Q^{\prime}
$$

em que o valor do resultado deve ser mantido abaixo de 0,10 . 
4.4.3 Determinação das áreas seccionais transversas dos axônios (ASTax), das bainhas de mielina (ASTbm) e das fibras mielínicas (ASTfm) do nervo isquiático

Utilizando-se o sistema analisador de imagens previamente descrito, foram obtidas três fotomicrografias com objetiva de 100x sob imersão, selecionadas aleatoriamente em cada corte. Em seguida, através de sorteio, foram medidas cinco fibras em cada fotomicrografia, perfazendo um total de 225 fibras e seus respectivos axônios de cada grupo. Uma vez realizadas as mensurações em $\mu^{2}{ }^{2}$, a ASTbm de cada fibra nervosa foi determinada a partir do cálculo da diferença entre a ASTfm e a ASTax (Figura 9).

Figura 9 - Determinação da área seccional transversa dos axônios (ASTax), das bainhas de mielina (ASTbm) e das fibras mielínicas (ASTfm) do nervo isquiático

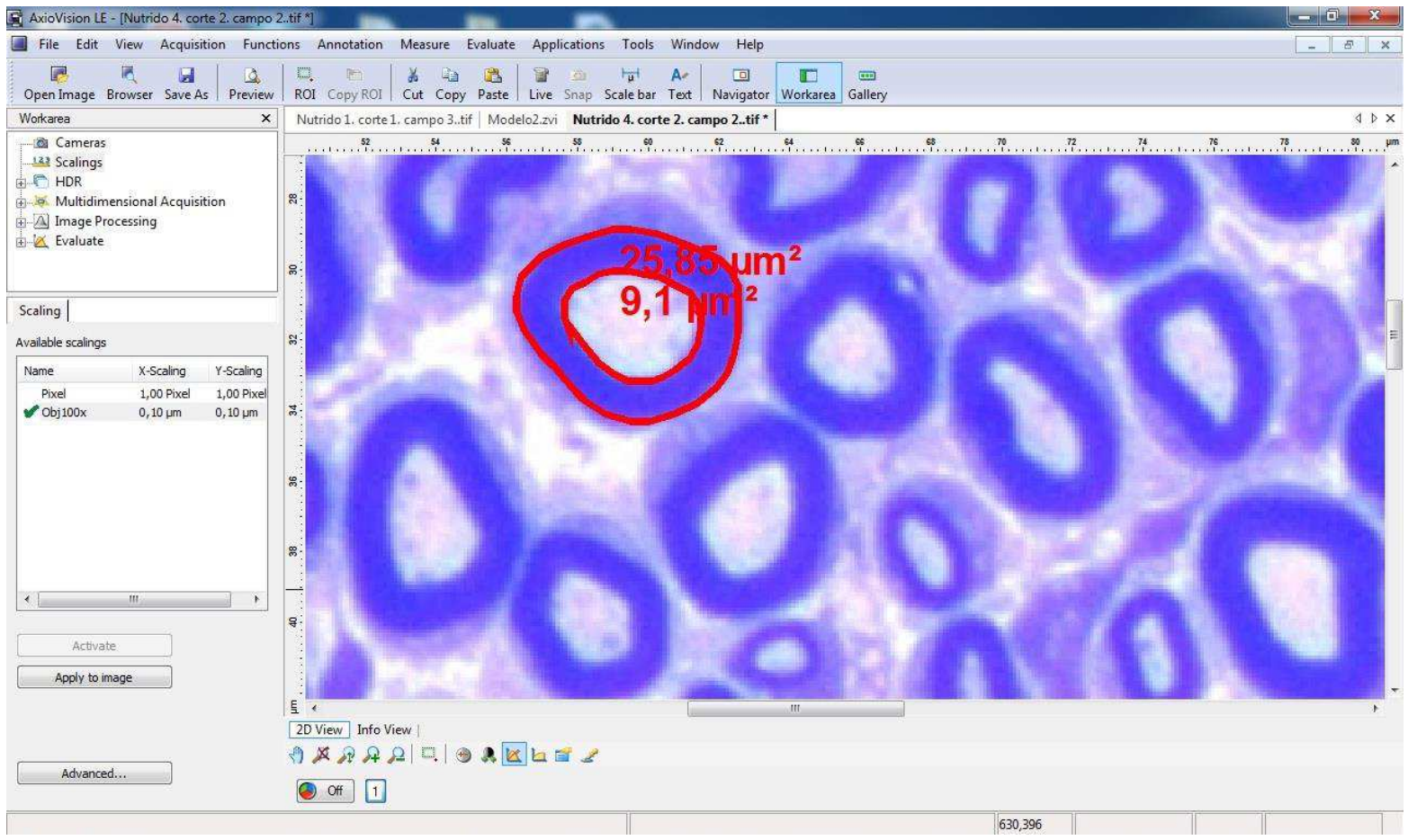

Fonte: (MENDONÇA, L. P., 2015).

Legenda: Demonstração de como é feita a medida de área seccional transversa do axônio e da fibra mielínica. 


\subsection{TRATAMENTO ESTATÍSTICO}

A análise estatística foi realizada com o objetivo de se comparar os grupos $\mathrm{N}$, S, e M com relação a cada uma das seguintes variáveis: peso corporal dos animais (g), área seccional transversa do nervo isquiático $\left(\mathrm{mm}^{2}\right)$, densidade de fibras nervosas mielínicas (fibras $/ \mathrm{mm}^{2}$ ), número total estimado de fibras nervosas mielínicas (fibras/nervo) e ASTax, ASTbm e ASTfn.

Os dados foram submetidos a uma análise de variância, ANOVA, com um fator grupo (3 níveis: N, S, M). A suposição de homogeneidade das variâncias foi verificada aplicando-se as testes de Cochran, Bartlet e Levene e, quando necessário, foram feitas comparações múltiplas pelo método de Tukey.

A fim de facilitar a interpretação foram construídos para todos os grupos de animais, histogramas nos quais os valores das áreas seccionais transversas dos axônios, das bainhas de mielina e das fibras nervosas mielínicas, todos obtidos em $\mu \mathrm{m}^{2}$, foram distribuídos em intervalo de classes de $2 \mu \mathrm{m}^{2}$ (axônios e bainhas de mielina) e $3 \mu \mathrm{m}^{2}$ (fibras nervosas mielínicas)

O nível de significância utilizado para todos os testes empregados foi $p<0,05$ (ZAR, 1984). 
RESULTADOS 


\section{RESULTADOS}

Os resultados obtidos a partir das análises qualitativas e quantitativas foram apresentados através de tabelas (com média $\pm \mathrm{DP})$, gráficos e figuras.

\subsection{ASPECTOS QUALITATIVOS}

Foram observadas algumas diferenças físicas e comportamentais quando comparado os animais de cada grupo experimental. Desde o nascimento dos filhotes, quando já havia distinção entre os animais da cada grupo ( $N$, $S$ e $M$ ), foram detectadas diferenças no comportamento da progenitora. Aquelas que receberam a dieta que caracterizou o grupo subnutrido (S) mostraram-se agitadas e agressivas, capazes de arrancar os próprios pelos, contrastando com as fêmeas do grupo nutrido (N) que não demostraram qualquer alteração comportamental. As fêmeas submetidas à dieta de Moçambique (Grupo $\mathrm{M}$ ) exibiam em alguns momentos comportamento agitado, porém, muito longe de serem agressivas como as do grupo $\mathrm{S}$.

Quanto aos filhotes, em geral, os processos de aparecimento de lanugem, deslocamento lateral das orelhas e abertura dos olhos que acontecem em média, entre $\circ 3^{\circ}$ e $\circ 12^{\circ}$ dias de vida pós-natal, geralmente ocorreu mais tardiamente nos grupos S e M, ou seja, a partir do $14^{\circ}$ dia. Nesses grupos foi nítido, ainda, um ligeiro atraso no aparecimento da pelagem (que ocorre por volta do $7^{\circ}$ dia de vida pós-natal) com os animais do grupo $S$ exibindo pelos curtos, menos vistosos e de distribuição escassa, que foi sendo normalizada por volta do $18^{\circ}$ dia. A divergência quanto a esses aspectos ficou menos evidente entre os grupos, todavia, principalmente no grupo S, essas características permaneceram em alguns indivíduos até a eutanásia.

Também em relação à atividade de locomoção dentro da caixa notou-se diferenças entre os grupos $\mathrm{N}$ e S. Por volta do $14^{\circ}$ dia de vida, os animais do grupo $\mathrm{N}$ locomoviam-se livremente, alimentavam-se de maneira independente de leite materno e da ração oferecida. Tal comportamento foi percebido no grupo $S$ somente na fase próxima a eutanásia (21 dias). 
O número de natimortos e de morte pós-natal foi alta nos grupos $\mathrm{S}$ e $\mathrm{M}$ o que não aconteceu no grupo N. Além disso, houve ainda o fenômeno de canibalismo por parte da mãe e entre os filhotes que aconteceu nos grupos S e M.

Quando o nervo isquiático foi analisado macroscopicamente notou-se apenas diferença em seu comprimento total, mas que estava relacionado em todos os casos com tamanho do filhote. Os animais do grupo $S$ eram os menores, seguidos dos animais do grupo M e em seguida os do grupo N (Figura 10).

Figura 10 - Ratos dos grupos N, M e S
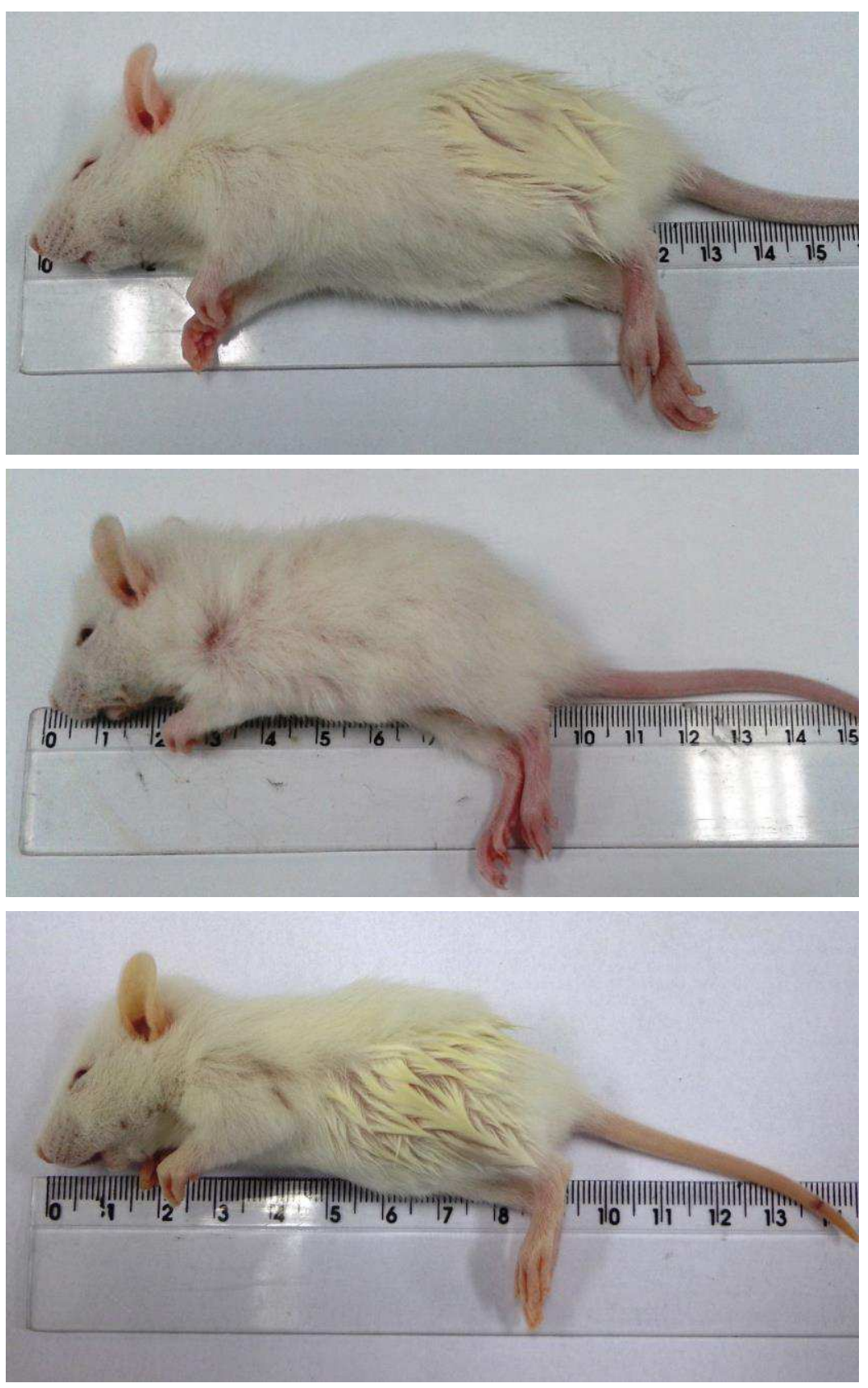

Fonte: (MENDONÇA, L. P., 2015).

Legenda: Observar o tamanho dos animais e a aparência dos pelos. 


\subsubsection{Microscopia Eletrônica de Transmissão (MET)}

Através da MET, verificaram-se em todos os grupos, fibras mielínicas de diferentes espessuras, correspondentes às camadas de mielina (Figura 11). Assim, foram notadas fibras delgadas e espessas e de diâmetros variáveis, porém com características que permitiram estabelecer diferenças entre os grupos. Enquanto no grupo $\mathrm{N}$ predominaram fibras de contorno transversal preferencialmente circular (Figuras 11A, B), as constituintes do nervo dos animais do grupo $\mathrm{M}$ exibiram, em sua maioria, fibras alongadas e de contorno tortuoso (Figuras $11 \mathrm{I}$, J). Já o grupo $\mathrm{S}$ caracterizou-se por apresentar fibras com contornos irregulares, a maioria de aspecto crenado (Figuras 11E, F).

Ao se analisar, em maior aumento, a disposição das camadas de mielina, tanto no grupo $\mathrm{N}$ como no grupo $\mathrm{M}$ as mesmas apresentaram-se compactadas, com poucos espaços entre as mesmas (Figuras 11C, D e 11K, L). No grupo S muitas fibras continham as camadas de mielina organizadas de forma concêntrica, porém, com espaços entre si (Figura 11G); aquelas compactadas exibiam espessuras variáveis ao longo do contorno da fibra (Figura $11 \mathrm{H})$.

\subsubsection{Microscopia Eletrônica de Varredura (MEV)}

Sob MEV, não foi possível detectar diferenças significativas entre os diferentes grupos $(\mathrm{N}, \mathrm{S}, \mathrm{M})$ quanto ao aspecto tridimensional do nervo isquiático. Desta forma, verificou-se que, quanto ao aspecto geral, o nervo estava constituído por axônios compactados, envolvidos por um epineuro de aspecto homogêneo (Figuras 12A, B). Ao se remover o epineuro, detectou-se logo abaixo do mesmo, o perineuro exibindo a forma de uma malha pantográfica de tecido colágeno de diferentes espessuras (Figuras 12D, F, G). O endoneuro envolvendo os axônios também foi observado, com sua superfície de aspecto homogêneo (Figuras 12E, H). 
Figura 11 - Microscopia Eletrônica de Transmissão

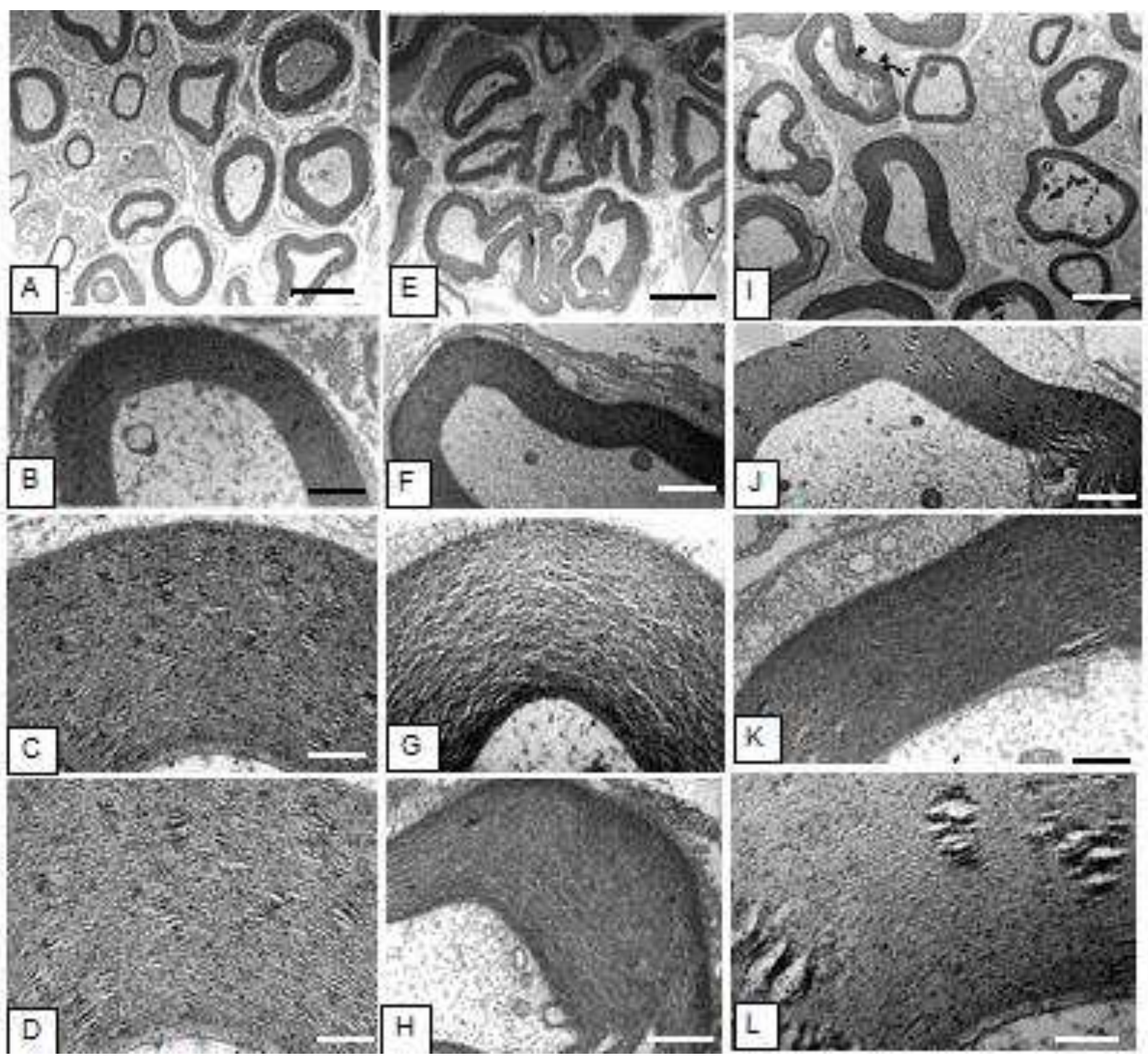

Fonte: (MENDONÇA, L. P., 2015).

Legenda: Micrografias eletrônicas de Transmissão do nervo isquiático de animais dos grupos $N(A-D)$; S (E-H) e M (I-L). (Barra de calibração: A,E,I: $5 \mu \mathrm{m} ; \mathrm{B}, \mathrm{F}, \mathrm{J}, \mathrm{H}: 1 \mu \mathrm{m} ; \mathrm{C}, \mathrm{G}, \mathrm{K}: 0,5 \mu \mathrm{m} ; \mathrm{D}, \mathrm{L}$ : $0,2 \mu \mathrm{m})$. 
Figura 12 - Microscopia Eletrônica de Transmissão

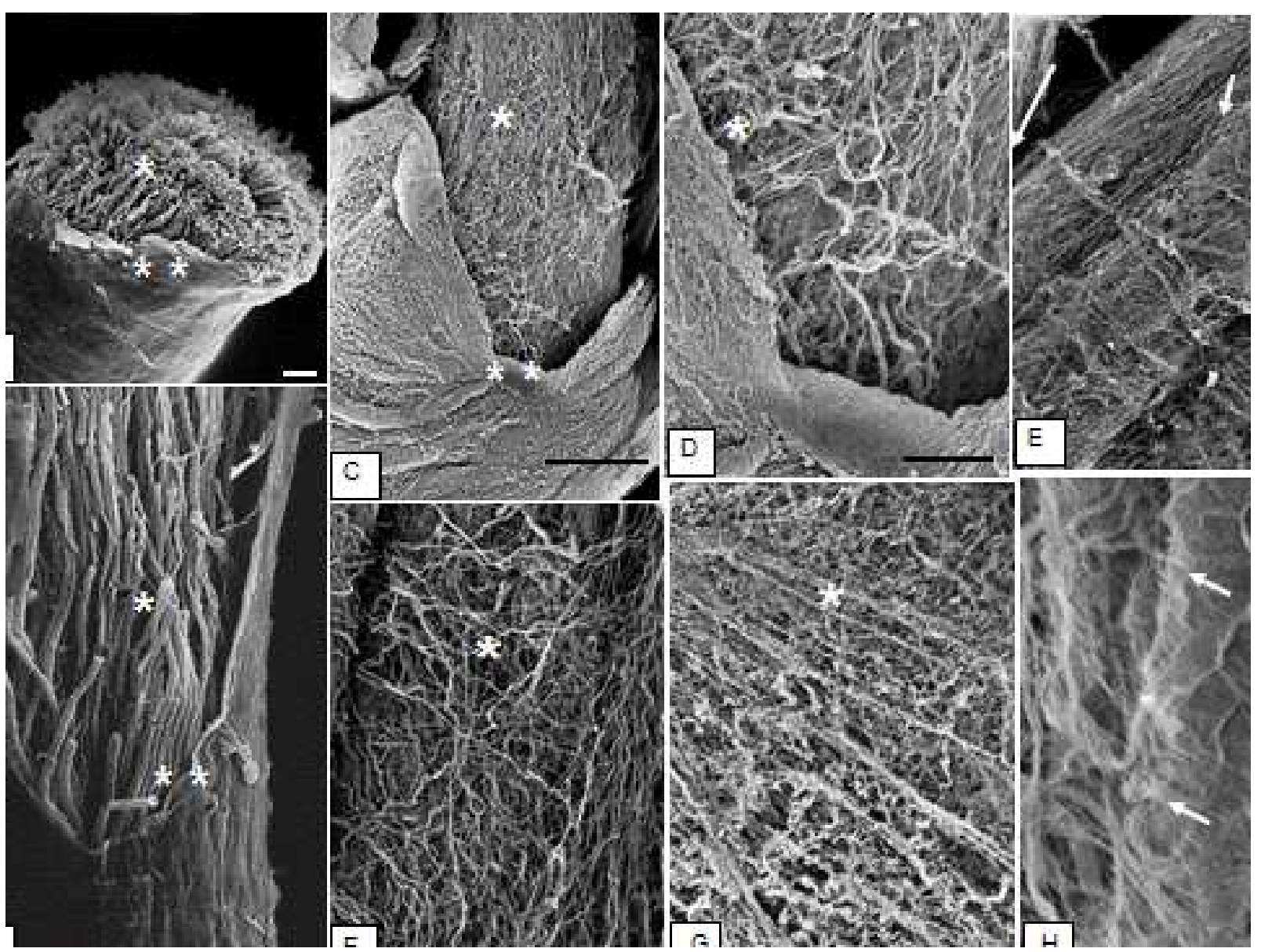

Fonte: (MENDONÇA, L. P., 2015).

Legenda: Micrografias do nervo isquiático de animais dos grupos N, S e M observados sob Microscopia Eletrônica de Varredura. A, B - Aspecto geral do nervo, destacando-se os axônios $\left(^{*}\right)$ e o epineuro $\left({ }^{* *}\right)$. C - Epineuro parcialmente removido $\left({ }^{*}\right)$, evidenciando-se a malha subjacente do perineuro $\left({ }^{* *}\right)$. D, F, G - Em maior aumento, o aspecto característico da disposição em malha esparsa $(D)$ e densa $(F)$ das fibras colágenas do perineuro $\left({ }^{*}\right)$. E - Dois axônios com poucas fibras do perineuro em sua superfície (seta longa), e o endoneuro subjacente (seta curta). H - Aspecto característico do endoneuro envolvendo um axônio (setas) (Barra de Calibração: A: $100 \mu \mathrm{m}$; B - D: $30 \mu \mathrm{m}$; E, G - $10 \mu \mathrm{m}$; H: $2 \mu \mathrm{m}$ ). 


\subsection{ASPECTOS QUANTITATIVOS}

Neste item serão descritos para todos os grupos experimentais ( $N$, S e $M)$ os dados referentes às comparações estatísticas entre as médias ( $\pm \mathrm{DP})$.

\subsubsection{Peso corporal dos animais $(\mathrm{g})$}

A média ( \pm desvio padrão) do peso corporal de animais dos diferentes grupos (N, S, M) estão ilustradas na tabela 1 e na figura 13.

A análise estatística desta variável demonstrou que houve diferença estatística entre os três grupos quando comparados entre si, sendo $S \neq N(p<0,05), S \neq M$ $(p<0,05)$ e $M \neq N(p<0,05)$. Assim, os animais do grupo $D$ foram os que apresentaram o menor peso corporal, os do grupo $\mathrm{N}$ o maior peso, enquanto que aqueles submetidos à dieta de Moçambique exibiram média intermediária.

Figura 13 - Representação gráfica das médias ( \pm desvio padrão) do peso corporal de animais dos grupos N, S e M

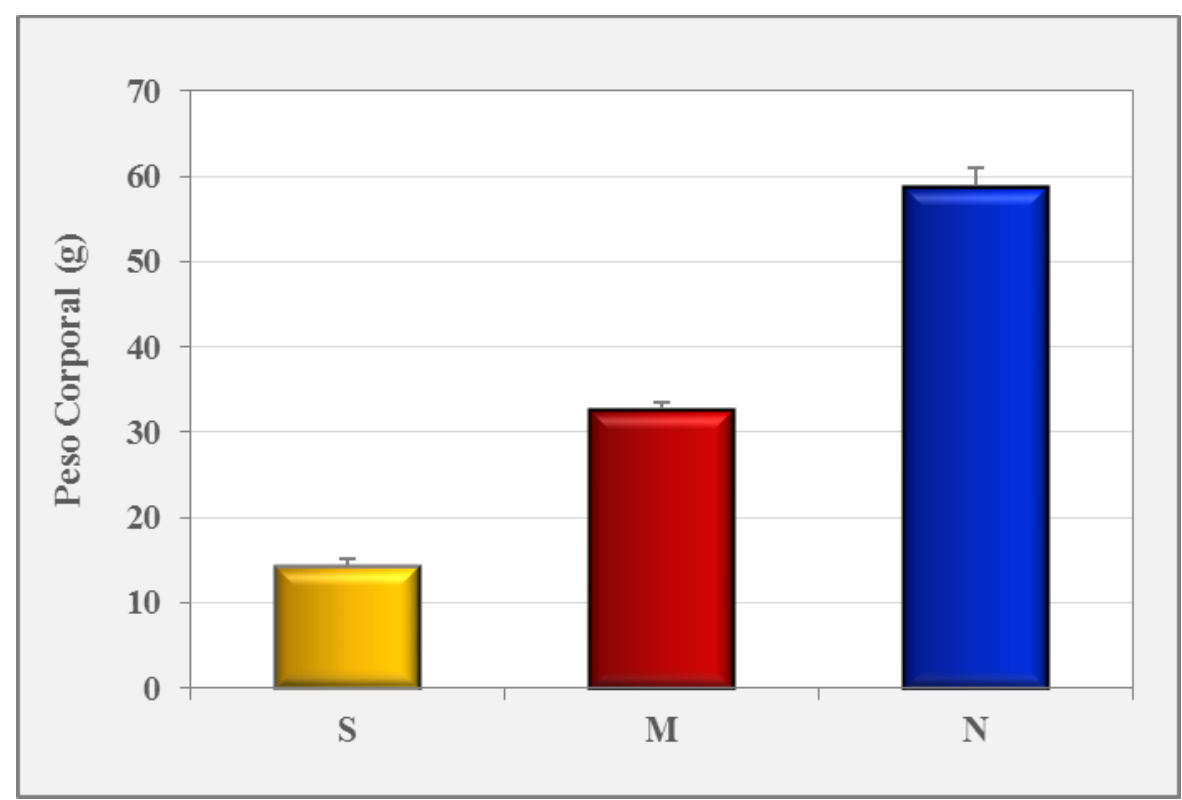

Fonte: (MENDONÇA, L. P., 2015).

Legenda: Utilizando o método de comparações múltiplas de Tukey foi verificada diferença estatística $(p>0,05)$ quando comparado o peso corporal e dos animais dos três grupos. 


\subsection{2 Área seccional transversa do nervo isquiático $\left(\mathrm{mm}^{2}\right)$}

Na tabela 1 e na figura 14A estão expressas as médias ( \pm desvio padrão) da ASTn dos animais dos grupos N, S e M.

Ao ser realizado a análise estatística desta variável, verificou-se que ocorreu diferença significativa entre os três grupos, com $P<0,001$. Comparando-se os grupos entre si com $p<0,05$, observou-se que $S \neq N$; $S \neq M$, e $M \neq N$, ou seja, os grupos $S$ e $N$ exibiram, respectivamente, a menor e a maior ASTn e o grupo M, um valor intermediário.

\subsubsection{Densidade de fibras nervosas mielínicas (fibras $/ \mathrm{mm}^{2}$ )}

As médias ( \pm DP) para esta variável dos grupos estudados $(N, S, M)$ estão expressas na tabela 1 e na figura 14B.

Através da análise estatística verificou-se que houve diferença significativa entre os grupos $S$ e $N$, e entre os grupos $S$ e $M(p<0,05)$; porém, entre os grupos $M$ e $\mathrm{N}$, não se detectou diferença estatística. Desta forma, os animais do grupo $\mathrm{S}$ foram os que apresentaram a maior densidade de fibras mielínicas, enquanto que no grupo $\mathrm{N}$ foi registrada a menor densidade.

\subsubsection{Número total estimado de fibras nervosas mielínicas (fibras/nervo)}

As médias $( \pm \mathrm{DP})$ do número total estimado de fibras nervosas mielínicas de ratos dos grupos $\mathrm{N}, \mathrm{S}$ e $\mathrm{M}$ são observadas na tabela 1 e na figura $14 \mathrm{C}$. Estatisticamente, não foram detectadas diferenças significativas entre os grupos $(p=0,196)$. 
Tabela 1 - Valores médios do peso corporal, da área seccional transversa do nervo, da densidade de fibras nervosas melínicas e do número total estimado de fibras mielínicas do nervo isquiático de animais dos grupos $\mathrm{N}, \mathrm{S}$ e M

\begin{tabular}{ccccc}
\hline Grupo & Peso $(\mathbf{g})$ & $\begin{array}{c}\text { AST do nervo } \\
\left(\mathbf{m m}^{\mathbf{2}}\right)\end{array}$ & Fibras $/ \mathbf{m m}^{2}$ & Fibras/nervo \\
\hline $\mathrm{N}$ & $58,74 \pm 2,28 *$ & $0,293 \pm 0,025 *$ & $11.247 \pm 1.347$ & $3.306,5 \pm 559,6$ \\
& & & & \\
S & $14,22 \pm 0,88 *$ & $0,193 \pm 0,026 *$ & $14.199 \pm 745 *$ & $2.746,1 \pm 440,6$ \\
& & & & \\
M & $32,65 \pm 0,89 *$ & $0,246 \pm 0,025 *$ & $12.148 \pm 695$ & $2.987,7 \pm 354,1$ \\
& & & & \\
\hline
\end{tabular}

Fonte: (MENDONÇA, L. P., 2015).

Legenda: Os valores correspondem à média \pm desvio padrão. Método de comparações múltiplas de Tukey.* $p<0,05$ em comparação aos demais grupos estudados. AST= Área Seccional Transversa.

Figura 14 - Representação gráfica das médias ( \pm desvio padrão) da área seccional transversa do nervo $(A)$ da densidade das fibras nervosas mielínicas $(B)$ e do número total estimado de fibras mielínicas (C) do nervo isquiático dos animais dos grupos $N, S$ e M
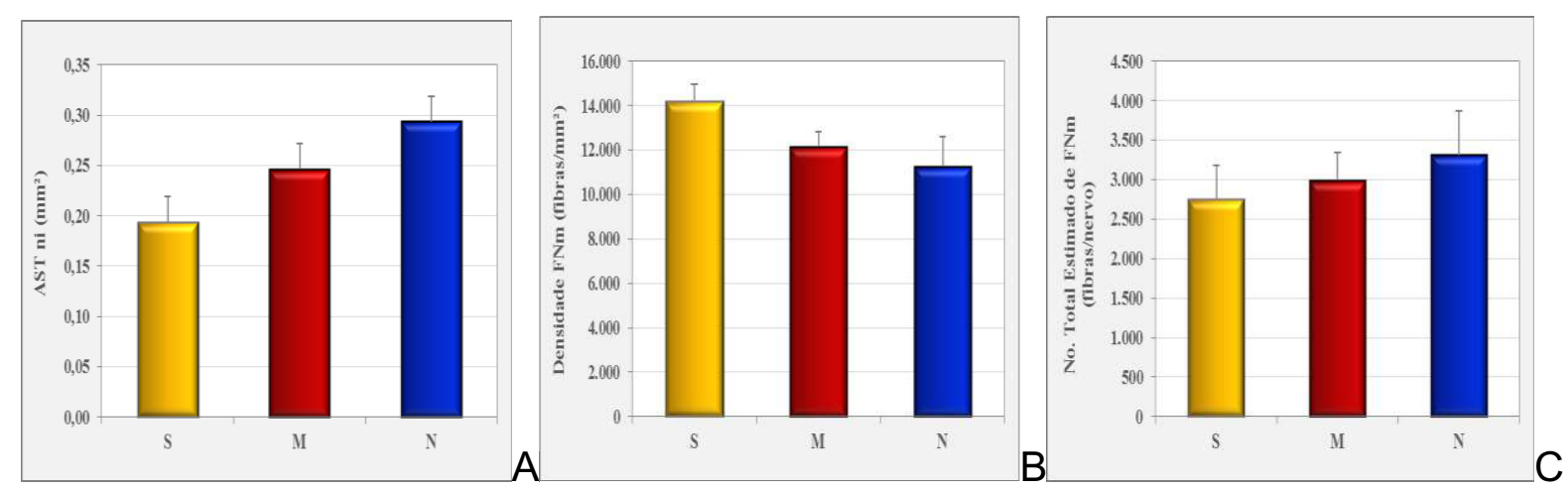

Fonte: (MENDONÇA, L. P., 2015).

Legenda: O método de comparações múltiplas de Tukey mostrou a existência de diferença significativa $(p<0,05)$ com relação à área seccional transversa do nervo quando comparado os três grupos entre si. Quanto a densidade das fibras foi observado diferença estatística entre os grupos $\mathrm{S}$ e $\mathrm{N}$ e entre os grupos $\mathrm{S}$ e $\mathrm{M}$. Com relação ao número total estimado de fibras mielínicas não foi detectada diferença significante entre os grupos. 


\subsection{5 Área seccional transversa dos axônios das fibras mielínicas (ASTax) do nervo isquiático $\left(\mu \mathrm{m}^{2}\right)$}

O número de axônios mensurados em cada grupo, bem como as médias, os DP e os valores mínios e máximos da ASTax do nervo isquiático de animais dos grupos N, S e M estão expressos na tabela 2. Ao se analisar estatisticamente essa variável, verificou-se que houve diferença significativa entre os três grupos: $S \neq N, S \neq$ $M$ e $M \neq N(p<0,001)$. Os axônios dos nervos dos animais do grupo $N$ e $S$ apresentaram, respectivamente, a maior e a menor ASTax, com valores intermediários para os animais do grupo $\mathrm{M}$.

A distribuição de frequência das ASTax ilustrada na figura 15 , permitiu verificar que no grupo $S$ a maior concentração delas esteve na faixa de 2 a $4 \mu \mathrm{m}^{2}$ (52\%); no grupo $\mathrm{N}$, entre 2 a $8 \mu \mathrm{m}^{2}(68 \%)$, e no grupo $\mathrm{M}$, entre 2 e $6 \mu \mathrm{m}^{2}(75 \%)$.

Tabela 2 - Médias, devios padrões, valores mínimos e máximos da área seccional transversa $\left(\mu m^{2}\right)$ dos axônios das fibras nervosas mielínicas do nervo dos animais dos grupos $\mathrm{N}, \mathrm{S}$ e M

\begin{tabular}{ccccc}
\hline Grupo & Média & DP & Mínimo & Máximo \\
\hline $\mathrm{N}$ & 6,71 & 3,06 & 1,09 & 20,12 \\
$\mathrm{~S}$ & 3,40 & 1,88 & 0,77 & 12,23 \\
$\mathrm{M}$ & 4,61 & 1,88 & 1,09 & 11,36 \\
\hline
\end{tabular}

Fonte: (MENDONÇA, L. P., 2015).

Nota: DP= Desvio Padrão. Método de comparações múltiplas de Tukey. $p<0,001$ entre os três grupos. 
Figura 15 - Representação gráfica da distribuição de frequência da ASTax do nervo isquiático dos animais dos grupos $\mathrm{N}, \mathrm{S}$ e M

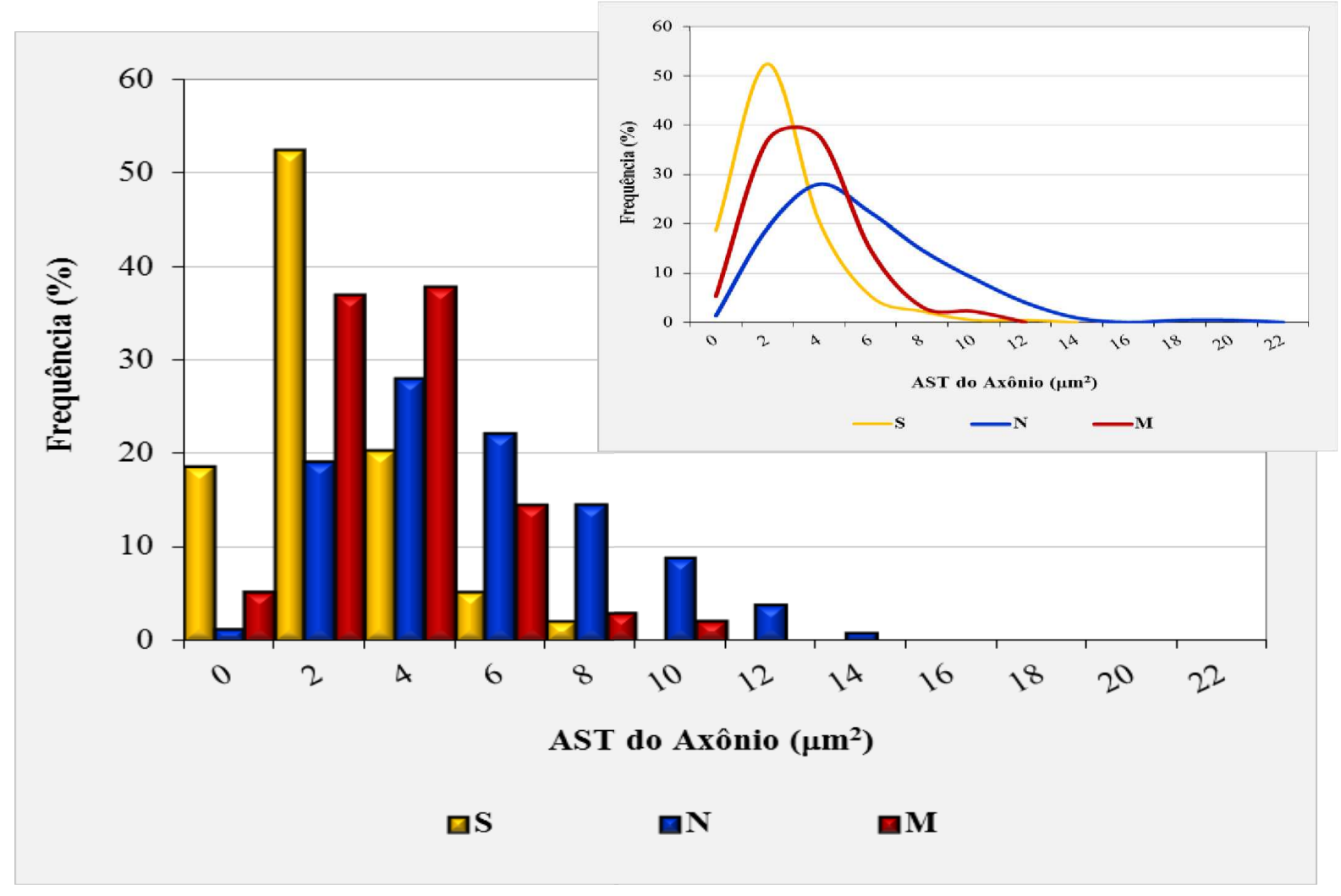

Fonte: (MENDONÇA, L. P., 2015).

Legenda: A distribuição de frequência das ASTax permitiu verificar que no grupo $S$ a maior concentração delas esteve na faixa de 2 a $4 \mu m^{2}(52 \%)$; no grupo $\mathrm{N}$, entre 2 a $8 \mu \mathrm{m}^{2}(68 \%)$, e no grupo $M$, entre 2 e $6 \mu m^{2}(75 \%)$.

\subsection{6 Área seccional transversa das bainhas de mielina das fibras mielínicas (ASTbm) do nervo isquiático $\left(\mu \mathrm{m}^{2}\right)$}

A tabela 3 expressa as médias ( \pm DP) e os valores mínimos e máximos da ASTbm do nervo isquiático de animais dos grupos $\mathrm{N}, \mathrm{S}$ e M.

Sob o aspecto estatístico, observou-se que $S \neq N$ e $M \neq N(p<0,001)$, com o grupo $\mathrm{N}$ exibindo a maior média, bem como o valor máximo atingido para essa variável. Em relação à distribuição de frequências (Figura 16), nota-se que no grupo $\mathrm{S}$, a maior concentração (52\%) esteve na faixa de 3 a $6 \mu^{2}$, e no grupo $M$, entre 3 e $9 \mu \mathrm{m}^{2}(73 \%)$. O grupo $\mathrm{N}$ exibiu grande variabilidade, distribuindo-se entre 9 e $21 \mu^{2}$, num total aproximado de $74 \%$. 
Tabela 3 - Médias, devios padrões, valores mínimos e máximos da área seccional transversa $\left(\mu \mathrm{m}^{2}\right)$ das bainhas de mielina das fibras nervosas mielínicas do nervo dos animais dos grupos $\mathrm{N}, \mathrm{S}$ e M.

\begin{tabular}{ccccc} 
Grupo & Média & DP & Mínimo & Máximo \\
\hline N & 15,99 & 5,08 & 4,94 & 34,17 \\
S & 6,19 & 3,11 & 1,0 & 17,1 \\
M & 6,91 & 2,76 & 2,31 & 16,52
\end{tabular}

Fonte: (MENDONÇA, L. P., 2015).

Nota: $\mathrm{DP}=$ Desvio Padrão. Método de comparações múltiplas de Tukey. $p<0,001$ entre os grupos $\mathrm{S}$ e $\mathrm{N}$ e entre o grupo $\mathrm{M}$ e $\mathrm{N}$.

Figura 16 - Representação gráfica da distribuição de frequência da ASTbm do nervo isquiático dos animais dos grupos $\mathrm{N}, \mathrm{S}$ e M

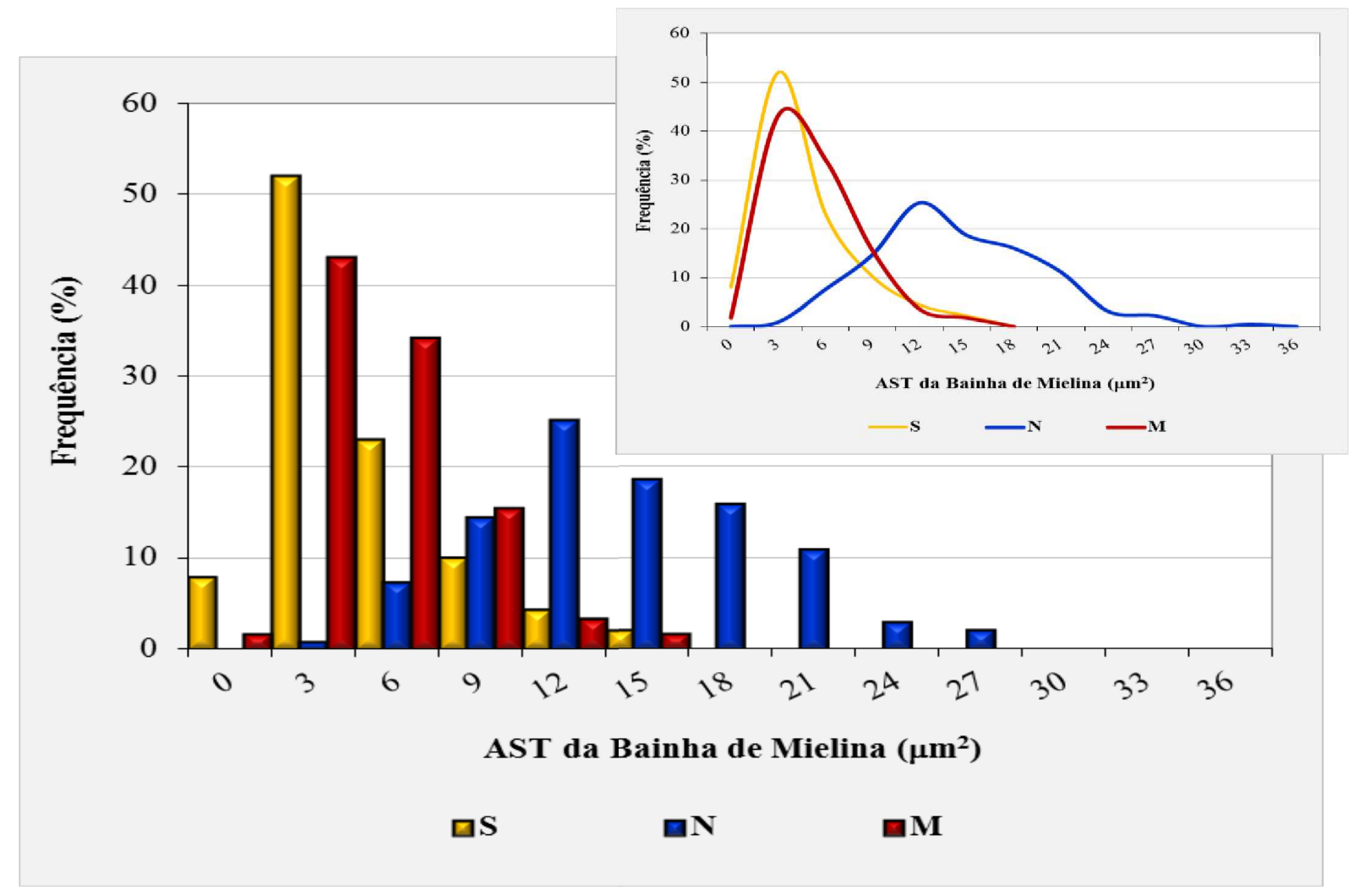

Fonte: (MENDONÇA, L. P., 2015).

Legenda: Nota-se que no grupo $S$, a maior concentração (52\%) esteve na faixa de 3 a $6 \mu m^{2}$, e no grupo $\mathrm{M}$, entre 3 e $9 \mu \mathrm{m}^{2}(73 \%)$. O grupo $\mathrm{N}$ exibiu grande variabilidade, distribuindo-se entre 9 e $21 \mu m^{2}$, num total aproximado de $74 \%$. 


\subsection{7 Área seccional transversa das fibras mielínicas (ASTfm) do nervo isquiático $\left(\mu \mathrm{m}^{2}\right)$}

As médias ( $\pm \mathrm{DP})$ e os valores mínimos e máximos da ASTfm do nervo de animais dos grupos N, S e D estão expressos na tabela 4.

Estatisticamente, verificou-se diferenças entre os grupos $\mathrm{S}$ e $\mathrm{N}$, e os grupos $\mathrm{M}$ e $N,(p<0,001)$ com os valores das médias dos grupos $S$ e $M$ muito próximos, e a média do grupo $\mathrm{N}$ com um valor diferenciado e elevado. Ao se analisar a distribuição de frequência da figura 17 , nota-se que o grupo $S$ tem a maioria das fibras mielínicas com áreas entre 3 e $9 \mu \mathrm{m}^{2}$ (76\%), e o grupo M com áreas entre 6 e $15 \mu \mathrm{m}^{2}$ (81\%). Já o grupo $\mathrm{N}$ mostrou uma distribuição bem heterogênea, com as áreas variando entre 12 e $30 \mu \mathrm{m}^{2}(71 \%)$, com destaque para a faixa entre 15 e $21 \mu \mathrm{m}^{2}$ (aproximadamente $40 \%)$.

Tabela 4 - Médias, devios padrões, valores mínimos e máximos da área seccional transversa $\left(\mu m^{2}\right)$ das fibras nervosas mielínicas do nervo dos animais dos grupos N, S e M

\begin{tabular}{ccccc}
\hline Grupo & Média & DP & Mínimo & Máximo \\
\hline N & 22,71 & 7,64 & 7,49 & 48,08 \\
S & 9,59 & 4,79 & 2,93 & 23,33 \\
M & 11,52 & 4,16 & 4,08 & 27,05 \\
\hline
\end{tabular}

Fonte: (MENDONÇA, L. P., 2015).

Nota: $\mathrm{DP}=$ Desvio Padrão. Método de comparações múltiplas de Tukey. $p<0,001$ entre os grupos $\mathrm{S}$ e $\mathrm{N}$ e entre o grupo $\mathrm{M}$ e $\mathrm{N}$. 
Figura 17 - Representação gráfica da distribuição de frequência da ASTfm do nervo isquiático dos animais dos grupos $\mathrm{N}, \mathrm{S}$ e $\mathrm{M}$

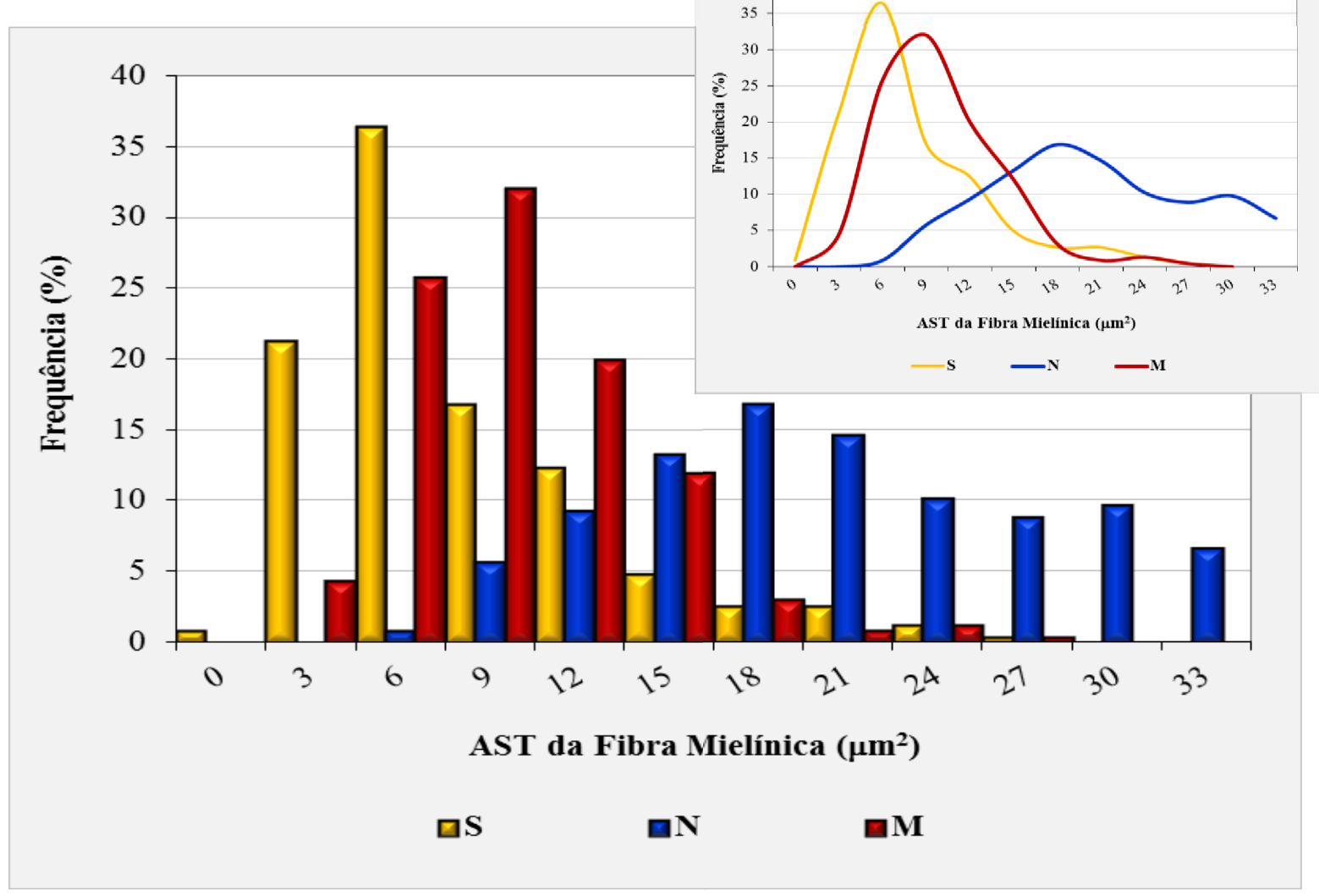

Fonte: (MENDONÇA, L. P., 2015).

Legenda: Observa-se que o grupo $S$ tem a maioria das fibras mielínicas com áreas entre 3 e $9 \mu \mathrm{m}^{2}$ (76\%), e o grupo $\mathrm{M}$ com áreas entre 6 e $15 \mu \mathrm{m}^{2}(81 \%)$. Já o grupo $\mathrm{N}$ mostrou uma distribuição bem heterogênea, com as áreas variando entre 12 e $30 \mu \mathrm{m}^{2}(71 \%)$, com destaque para a faixa entre 15 e $21 \mu \mathrm{m}^{2}$ (aproximadamente 40\%). 
DISCUSSÃO 


\section{DISCUSSÃO}

Neste capítulo serão discutidos os resultados obtidos neste estudo relacionados aos aspectos morfológicos macroscópicos e microscópicos

\subsection{OBSERVAÇÕES GERAIS QUALITATIVAS E QUANTITATIVAS SOBRE O MODELO ANIMAL E O PROTOCOLO EXPERIMENTAL}

Muitos autores utilizam animais de pequeno porte para experimentos e essa escolha se deve a diversos fatores, como a facilidade na obtenção dos espécimes e na manipulação experimental em laboratório, o fácil acompanhamento do animal, suas intercorrências, desenvolvimento. Outro fator é a baixa mortalidade, gerando um custo mais baixo às pesquisas que necessitam maior número de animais (AKSOY et al., 2002). Como modelo animal do presente estudo foi utilizado o Rattus Novergicus da linhagem Wistar heterogêneo que, Segundo Braga (2010) possui em sua constituição genética $90 \%$ de heterozigose fato que determina uma alta diversidade genética em um mesmo grupo, e que permite uma população confiável de populações naturais.

Há ainda outras justificativas para o uso desse modelo animal, como a puberdade que acontece a partir de 30 dias, e a maturidade sexual que se dá dos 50 a 60 dias, (VIAL et al., 2005), informações interessantes para a escolha das idades ideais para o acasalamento (entre 60 e 90 dias de vida), com vistas a maior taxa de sobrevivência ao se considerar os animais subnutridos, que apresentam maior instabilidade no momento do acasalamento e menor número de filhotes nascidos vivos. Dentre muitos benefícios deste modelo animal, é preciso considerar também, segundo Nóbrega (1986), que quando se transpõe o modelo experimental para humanos, tem que haver mais cuidado na interpretação dos resultados, se tratando de subnutrição, sua imposição sobre os animais traz efeitos mais intensos comparado ao ser humano.

Muitos estudos anteriores têm utilizado protocolos experimentais semelhantes ao aplicado neste estudo (GONÇALVES, 2001; CASTELUCCI et al., 2002; BINOTTI, 
2003; BOLDRINI, 2003; BRANDÃO et al., 2003; AKAMATSU, 2006; BAUTZ, 2006; GOMES et al., 2006; MIRANDA, 2006; OLIVEIRA, 2006; BAPTISTA, 2008; CAVALLI, 2010; HABACUQUE, 2010; LUIZ, 2011; VONO, 2011, BOLINA-MATOS, 2012), reduzindo assim a chance de erros. $E$, ainda com intuito de evitar vieses e minimizar altos desvios padrões, buscou-se padronizar o número de filhotes por ninhada considerando que havia ninhadas numerosas e isso influenciava quando comparado a ninhadas menores cuja quantidade de leite oferecido era maior.

Em uma análise qualitativa foi possível perceber diferenças comportamentais da progenitora e dos filhotes, além de diferenças físicas perceptíveis dos grupos $\mathrm{S}$ e M em comparação ao grupo N. Quando se discute o ato de canibalismo da mãe em relação aos filhotes de dos filhotes entre si observado apenas no grupo subnutrido, Diaz Del Castilho (1975), afirma que este pode ser um ato associado ao estresse causado pela escassez proteica aliada a outras situações adversas. Andrade, Pinto e Oliveira (2002), explicam que estas situações adversas ocasionam respostas fisiológicas no animal e entre elas, pode-se citar: alimentação, mudança de trocador, manejo, isolamento, métodos experimentais, barulho excessivo. No presente estudo todos estes fatores foram cuidadosamente minimizados, mesmo não sendo possível isola-los completamente destes eventos estressante.

Braga (2010) afirma que o rato é um animal muito sensivel às alterações de odor, textura e aparências dos alimentos, sendo assim, é preciso considerar que na fase inicial de acasalamento, as fêmeas passam de uma alimentação balanceada para uma dieta hipoproteica, fato que pode contribuir para um estresse cumulativo que levou ao canibalismo.

Quanto ao atraso no desenvolvimento dos pelos, o estudo Shrader e Zeman (1969), mostraram que o grupo de ratos subnutridos apresentou não só esse atraso, mas também menor densidade numérica e tamanhos menores de pelos comparado ao grupo controle. Em análise histológica, foi visto que a reatividade enzimática nas camadas da epiderme, nas células epiteliais dos brotos rudimentares do pelo, nos componentes do tecido conjuntivo e nas papilas em formação apresentaram atividade enzimática consideravelmente reduzida.

Durante a fase de amamentação, foi percebido um atraso no desenvolvimento do processo de locomoção dos animais subnutridos. Segundo Bolina-Matos (2012) uma vez reduzida a oferta de proteína para o processo de catabolismo, resultará na menor oferta de aminoácidos e, desta forma, não serão sintetizadas novas proteínas 
por ação do anabolismo, ou seja, não haverá formação de proteínas essenciais para o desenvolvimento e maturidade adequada dos órgãos.

No presente estudo observou-se menor peso corporal dos animais que receberam dietas com baixo teor proteico, em especial o grupo subnutrido. Segundo Sawaya (2006) o baixo peso é um dos principais dados adquiridos ao se falar de qualquer tipo de subnutrição. A análise estatística desta variável neste estudo demostrou significância entre os três grupos e os animais que receberam a dieta de Moçambique se mantiveram numa posição intermediária entre os subnutridos e os nutridos.

De acordo com Langley-Evans (2001) uma gama de evidências epidemiológicas indica que a experiência da subnutrição num estágio pré-natal pode ser um fator determinante para o risco de desenvolvimento de doença cardiovascular. Segundo ele, o baixo peso e as desproporções corporais ao nascer decorrente da subnutrição são fortes indicadores de risco elevado para o desenvolvimento de doenças na vida adulta. O estado nutricional tem sido determinante para o desenvolvimento do feto. A avaliação e validade do conceito de estado nutricional é altamente depende de estudos experimentais em animais. A alimentação baseada em dietas com baixo teor proteico na gestação resulta em animais com perturbações no crescimento fetal e peso ao nascimento. Os filhotes de ratos alimentados com dietas pobres em proteína apresentam uma série de alterações metabólicas e fisiológicas.

No presente estudo a quantidade e qualidade do leite materno pode ter sido influenciada pela deficiência proteica da dieta oferecida à mãe, e essa a principal fonte de alimento para os filhotes em todo o período de avaliação. Este fato pode justificar para o baixo peso apresentado. Hsueh, Agustin e Chow (1967) comprovam que a quantidade de proteína presente na dieta da mãe exerce influência sobre o peso e tamanho dos filhotes. E segundo Marin et al.(1995), em experimento com subnutrição materna, foram apresentados dados que comprovam a baixa qualidade do leite, com menor concentração de nutrientes essenciais.

Stewart, Preece e Sheppard (1975), na avaliação dos efeitos da subnutrição proteica de 12 gerações seguidas de ratos, puderam perceber que na já na primeira geração o filhote apresentava baixo peso, e a cada geração este déficit foi aumentando progressivamente. 
Corroborando com o presente estudo, Ahmad e Rahman (1975) apresentaram resultados que comprovam estatisticamente o baixo peso corporal de filhotes de fêmeas subnutridas em comparação com o grupo controle. Em desacordo, o trabalho de Clos et al. (1977) não evidenciou resultados significativos em relação ao peso corporal de ratos provenientes de mãe subnutridas.

Diaz del Castillo (1975) em estudo com gestantes submetidas à dietas hipoproteicas, percebeu uma alta incidência de aborto, natimortos, mortes neonatais ou crianças abaixo do peso. Em estudo com humanos, Caulfield et al. (2004) objetivaram analisar a o risco de morte por causa do baixo peso de recém-nascidos assim como estimar o número de mortes atribuídas ao mesmo fator a partir de dados obtidos da análise de 310 inquéritos nacionais de desnutrição, as informações de prevalência foram então calculadas pelas mortes atribuídas exclusivamente à desnutrição. Como resultado, concluíram que o risco relativo de mortalidade decorrente do baixo peso é elevado, no geral, $52,2 \%$ de todas as mortes de recémnascidos foram atribuídas à desnutrição e concluir que os esforços para reduzir a desnutrição deve ser uma prioridade política.

\subsection{ASPECTOS MORFOQUANTITATIVOS}

Tem sido descrito que a desnutrição grave que ocorre no período pós-natal é capaz de determinar lesões cerebrais permanentes, diretamente proporcionais ao grau da desnutrição. Estas lesões são responsáveis pelo retardo do desenvolvimento neuropsicomotor de crianças desnutridas, o qual pode ser reversível se a recuperação da desnutrição se faz em condições socioculturais favoráveis, com estimulação psicomotora da criança (CARRAZA, 1994; DANTAS et al., 2005). Além dos efeitos dessa condição na parte central do sistema nervoso (SNC), estudos com desnutrição proteica em ratos jovens comprovam que a mesma promove um retardo no desenvolvimento da divisão autônoma do sistema nervoso (SNA), tornando-se reversíveis com a recuperação proteica, em fases precoces do desenvolvimento animal (CASTELUCCl et al., 2002; GOMES et al., 2006).

Até seus estudos no início da década de 1980, Delanei et al. (1981) afirmavam que avaliações realizadas concomitantemente no encéfalo (SNC) e no 
nervo tibial (SNP) de rato desnutridos não tinham sido realizadas. Particularmente no nervo tibial, os autores detectaram uma tendência da circunferência das fibras mielínicas serem menores nos animais desnutridos, o que foi confirmado tanto nos animais do grupo $\mathrm{S}$, como naqueles do grupo $\mathrm{M}$.

Se sob MEV não foram detectadas diferenças entre os grupos no que se refere aos envoltórios do nervo, na ultraestrutura (MET), muitas das fibras dos grupos S e M diferiram do padrão circular presente nos animais do grupo N. Além disso, deve-se destacar que no grupo $S$ muitas fibras continham as camadas de mielina organizadas de forma concêntrica, porém, com espaços entre si.

Essas descrições corroboram com os estudos de Binotti (2003) que demonstrou em ratos jovens desnutridos fibras nervosas mielínicas com contorno irregular, achatado e muitas vezes poligonal; Oldfors e Persson (1982) que relataram fibras pregueadas em macacos subnutridos, e Roy et al. (1972) que descreveram em nervos periféricos de ratos subnutridos nódulos nas fibras que se projetavam para o interior do axoplasma, e invaginações na bainha de mielina.

Em relação à ASTn, também verificou-se que ocorreu diferença significativa entre os três grupos, com as animais $\mathrm{S}$ e $\mathrm{N}$ exibindo, respectivamente, a menor e a maior área e o grupo M, um valor intermediário; porém, ainda menor do que aquela do grupo $\mathrm{N}$.

No trabalho de Wiggins et al. (1984) foi observado uma discreta redução desta variável no nervo óptico de ratos submetidos a uma restrição alimentar pósnatal, e no estudo de Conradi et al. (1989) ratos com 12 dias de vida submetidos a subnutrição proteica pré e pós-natal exibiram uma redução da área seccional transversa do nervo óptico, que foi maior em animais com 6 meses.

No nervo tibial, Cornblath e Brown (1988) encontraram uma redução da área fascicular que chegou a 50\% em comparação ao grupo de animais nutridos e no estudo de Binotti (2003) na avaliação do nervo alveolar inferior de ratos subnutridos, as médias da área seccional transversa do grupo subnutrido eram de 25 a $30 \%$ menores que as do grupo nutrido. A autora justifica o fato não somente à dieta a qual eles foram submetidos, mas também ao nervo em questão, bom como suas relações com estruturas adjacentes, evidenciando que o nervo alveolar exibe características estruturais peculiares ao transitar pelo canal da mandíbula.

Essa variabilidade pode estar relacionada não somente ao modelo experimental de subnutrição empregado neste estudo, mas também se deve atentar 
ao tamanho dos animais como um todo, ou seja, aqueles que receberam dietas hipoproteicas apresentar retardo em sua maturidade de maneira geral, bem como nas dimensões corporais, resultando assim, em um menor tamanho de órgãos e tecidos.

Em relação à densidade de fibras nervosas mielínicas, foi visto que os animais do grupo $S$ foram os que apresentaram a maior densidade de fibras mielínicas, enquanto que no grupo $\mathrm{N}$ foi registrada a menor densidade, havendo diferença significativa entre os grupos $\mathrm{S}$ e $\mathrm{N}$, e entre os grupos $\mathrm{S}$ e $\mathrm{M}$.

Conradi et al. (1989) encontraram no nervo óptico de ratos subnutridos durante os períodos pré e pós-natal, com 20 dias de idade, um aumento do número de axônios por área em torno de $25 \%$ e aos 6 meses, um aumento de $17 \%$ a partir dos $25 \%$. Cornblath e Brown (1988) encontraram uma densidade de fibras mielínicas correspondente ao dobro daquela encontrada em animais nutridos. Há ainda resultados que não evidenciaram o mesmo resultado, como o de Rana et al. (1991) que na análise dos nervos ulnar e tibial de macacos jovens submetidos à subnutrição proteica, observaram um valor menor de densidade comparado ao grupo nutrido.

Em análise, relacionando as duas variáveis anteriores: ASTn e densidade das fibras nervosas mielínicas, é possível perceber que elas são inversamente proporcionais, o grupo $\mathrm{N}$ apresentou a AST menor que os outros grupo e também a maior densidade de fibras nervosas. Este pode ter sido um fator compensatório, ou seja, numa maior quantidade aglomerada de fibras em um nervo com área menor. Essa compensação pode ser advinda da necessidade de condução nervosa não suprida possivelmente por causa da subnutrição. Ao mesmo tempo, deve-se destacar que embora haja maior quantidade de fibras numa mesma área nervosa, essas fibras exibem características não convencionais como citado na análise qualitativa.

Quando se trata do número total estimado de fibras nervosas mielínicas, estatisticamente, não foram detectadas diferenças significativas entre os grupos. $\mathrm{O}$ que corrobora com o estudo de Bedi e Warren (1983) que ao investigar a subnutrição proteica em ratos de 50 dias de idade, também não obtiveram resultados estatísticos para essa variável. 
No estudo de Hedley-Whyte e Meuser (1971), na avaliação do nervo óptico de ratos com 18 dias de vida, a desnutrição diminuiu discretamente o número total de fibras mielínicas.

Um fator importante a ser destacado é que, ainda que não haja diferença estatística nestes valores, os gráficos do número total estimado de fibras nervosas mielínicas e da densidade das fibras nervosas mielínicas exibiram dados inversamente proporcionais, remetendo à ideia de que, apesar de serem mais densos, os nervos de animais desnutridos não apresentaram um maior número de fibras nervosas, o mesmo acontece quando se observa que os nervos dos animais nutridos apesar de serem menos densos e maiores em área, não possuem maior número de fibras nervosas. Vale salientar que o grupo que recebeu a dieta padrão de Moçambique se manteve em ambos os casos em uma posição intermediária com tendências a semelhanças com o grupo subnutrido.

Quando se avaliou as áreas seccionais transversas ASTax, ASTbm e ASTfm, foram verificadas diferenças estatísticas entre os grupos. Estes dados podem ser considerados coerentes, uma vez que a literatura demonstra de maneira geral, que a subnutrição determina efetivamente uma redução ou retardo no processo de mielinização e no crescimento axonal. Sima et al. (1971), observaram redução no diâmetro das fibras nervosas do nervo isquiático de animais subnutridos; Hedley-Whyte e Meuser (1971) verificaram também no nervo isquiático, bainhas de mielina mais delgadas, e Delaney et al. (1981) observaram que a circunferência do axônio e a espessura da bainha de mielina das fibras nervosas eram menores em ratos subnutridos.

Os dados aqui expostos concordam com Gopinath et al. (1983) que observaram no nervo isquiático de ratos um atraso no desenvolvimento do axônio, no processo de mielinização, a ocorrência de uma maior proporção de fibras mielínicas de pequeno diâmetro, e a redução na espessura da bainha de mielina, fato este também verificado por Roy et al. (1972).

Particularmente às ASTbm e ASTfm não foram observadas diferenças estatísticas entre os grupos S e M. Além disso, a proporção entre a ASTfm/ASTbm, também diminuiu nesses grupos, comparativamente ao grupo $\mathrm{N}(\mathrm{N}: 70 \%$; $: 64 \%$ e M:60\%), evidenciando uma proximidade entre as consequências da subnutrição proteica severa decorrente da baixíssima quantidade de proteína animal e de uma dieta baseada apenas em proteína vegetal, como aquela utilizada em Moçambique. 
Desta forma ao se avaliar que pode-se considerar que a dieta de Moçambique pode produzir efeitos nas fibras mielínicas como a subnutrição, ou seja, interferir na formação das lamelas, o que de acordo com Segura et al. (2004) resulta em alterações severas na geração e propagação dos potenciais de ação em nervos, e no SNC facilita episódios convulsivos em animais (Stern et al, 1974). 
CONCLUSÕES 


\section{CONCLUSÕES}

De acordo com a metodologia aplicada no presente estudo e os resultados obtidos acerca das repercussões morfológicas causadas pela subnutrição proteica no nervo isquiático e seus constituintes, pode-se concluir que:

1. Os animais dos grupos $S$ e $M$ exibiam diferenças comportamentais da progenitora e filhotes assim como atraso no desenvolvimento corporal. Ao final do período estabelecido para análise, o desmame (21 dias) os filhotes subnutridos apresentaram também características físicas diferentes dos animais $\mathrm{N}$;

2. Os grupos subnutridos e Moçambique exibiram características morfológicas quantitativas diversas em relação aos seus respectivos controles nutridos;

3. Comparativamente ao grupo controle $(\mathrm{N})$, as menores médias para os parâmetros peso corporal e área seccional transversa do nervo, foram verificadas nos animais subnutridos, ao passo que os animais que receberam a dieta padrão de Moçambique exibiram médias intermediárias.

4. A subnutrição não alterou número total estimado de fibras nervosas mielínicas, porém há uma inversa proporcionalidade entre a ASTn e densidade das fibras nervosas mielínicas, sendo o grupo $S$ aquele que apresentou a menor ASTn e maior densidade

5. As ASTbm e ASTfm não demonstraram diferenças significativas entre os grupos $S$ e M. Além disso, a proporção entre a ASTfm/ASTbm, também diminuiu nesses grupos, mostrando proximidade entre as consequências da subnutrição proteica severa decorrente da baixíssima quantidade de proteína animal e de uma dieta baseada apenas em proteína vegetal, como aquela utilizada em Moçambique 
Desta forma, pode-se afirmar que o modelo de restrição proteica pré e pósnatal imposta aos animais durante o período de crescimento, foi suficiente para verificar alterações morfológicas, e que a subnutrição afeta o desenvolvimento do nervo e ainda desenvolve mecanismos compensatórios para minimizar estes prejuízos. Sendo assim, diante de todos os resultados e das proposições realizadas, não se descarta a hipótese de que a subnutrição proteica, em determinados períodos, seja responsável por alterações irrecuperáveis no nervo isquiático de ratos Wistar. 
REFERÊNCIAS 


\section{REFERÊNCIAS}

AKAMATSU, F. E. Características estruturais, ultra-estruturais e morfométricas do plexo subepicárdio de ratos submetidos à desnutrição proteica pré e pósnatal e a renutrição pós-natal. 2006. 157 f. Dissertação (Mestrado em Ciências Morfofuncionais) - Instituto de Ciências Biomédicas, Universidade de São Paulo, São Paulo, 2006.

AKSOY, M. H.; VARGEL, I.; CANTER, I. H.; ERK, Y.; SARGON, M.; PINAR, A.; GÜLER TEZEL, G. A new experimental hypertrophic scar model in guinea pigs. Aesthetic Plastic Surgery, v. 26, p. 388-396, 2002.

BAPTISTA, J. S. Repercussões morfológicas no timo de ratos jovens submetidos à desnutrição proteica e à renutrição precocemente corrigida. 2008. 107 f. Dissertação (Mestrado em Ciências Morfofuncionais) - Instituto de Ciências Biomédicas, Universidade de São Paulo, São Paulo, 2008.

BARKER, D. J. Fetal nutrition and cardiovascular disease in later life. Br. Med. Bull., v. 53, n. 1, p. 96-108,1997.

BARKER, D. J.; GLUCKMAN, P. D.; GODFREY, K. M.; HARDING, J. E.; OWENS, J. A.; ROBINSON, J. S. Fetal nutrition and cardiovascular disease in adult life. Lancet, v. 341, n. 8850 , p. $938-941,1993$.

BATISTA-FILHO, M.; RISSIN, A. A transição nutricional no Brasil: tendências regionais e temporais. Cadernos de Saúde Pública, v. 19, p. S181-S191, 2003. Suplemento, 1.

BAUTZ, W. G. Repercussões morfológicas da desnutrição proteica pré e pósnatal e da renutrição pós-natal no reparo da mucosa e do osso alveolar da mandíbula de ratos após a extração do primeiro molar. 2006. 81 f. Dissertação (Mestrado em Ciências Morfofuncionais) - Instituto de Ciências Biomédicas, Universidade de São Paulo, São Paulo, 2006.

BEDI, K. S.; WARREN, M. A. The effects of undernutrition during early life on the rat optic nerve fibre number and size-frequency distribution. J. Comp. Neurol., v. 219, n. 2, p 125-132, 1983.

BINOTTI, C. B. Repercussões morfológicas da desnutrição proteica pré e pósnatal e da renutrição pós-natal sobre o nervo alveolar inferior de ratos jovens. 2003. 94 f. Tese (Doutorado em Ciências Morfofuncionais) - Instituto de Ciências Biomédicas, Universidade de São Paulo, São Paulo, 2003.

BLACK, R. E.; ALLEN, L. H.; BHUTTA, Z. A.; CAULFIELD, L. E.; DE ONIS, M.; EZZATI, M.; MATHERS, C.; RIVERA, J. For the Maternal and Child Undernutrition Study Group. Maternal and child undernutrition: global and regional exposures and health consequences. Lancet, v. 371, n. 9608, p. 243-260, 2008. 
BOLDRINI, S. C. Efeitos da desnutrição pré e pós-natal e da renutrição pósnatal sobre o crescimento craniofacial de ratos Wistar: análise craniométrica morfoquantitativa e ultra-estrutural. 2003. 69 f. Tese (Doutorado em Ciências Morfofuncionais) - Instituto de Ciências Biomédicas, Universidade de São Paulo, São Paulo, 2003.

BOLINA-MATOS,R. S. Aspectos histoquímicos e quantitativos da renutrição precoce e tardia no córtex cerebral de ratos Wistar. 2012. 178 f. Tese (Doutorado em Ciências) Faculdade de Medicina Veterinária e Zootecnia, Universidade de São Paulo, São Paulo, 2012.

BRAGA, L. M. G. M. O animal como um modelo experimental: noções básicas de genética, sanidade, alojamento e manutenção de animais de laboratório. In: FEIJÓ, A. G. S.; BRAGA, L. M. G. M.; PITREZ, P. M. C. (Org.). Animais na pesquisa e no ensino: aspectos éticos e técnicos. Porto Alegre: Edipucrs, 2010. 171 - 186 p.

BRANDÃO, M. C. S.; ANGELIS, R.C.; SOUZA, R. R.; FRÓES, L. B.; LIBERTI, E. A. Effects of pre- and post-natal protein energy deprivation on the myenteric plexus of the small intestine: a morphometric study in weanling rats. Nutrition Research, v. 23, n. 2, p. 215-223, 2003.

CARIAS, D.; CIOCCIA, A. M.; HEVIA, P. Grado de concordancia entre la digestibilidad de proteínas animales y vegetales med idas in vivo e in vitro y su efecto sobre el cómputo químico. Arch. Latinoam. Nutrición., v. 45, n. 2, p. 111-116, 1995.

CASTELUCCI, P.; DE SOUZA, R. R.; ANGELIS, R. C.; FURNES, J. B.; LIBERTI, E. A. Effects of pré- and postnatal protein deprivation and postnatal refeeding on myenteric neurons of the rat large intestine: a quantitative morphological study. Cell and Tissue Research, v. 310, n. 1, p. 1-7, 2002.

CAVALLI, M. A. Avaliação morfoquantitativa dos efeitos da subnutrição e da renutrição proteica no processo condilar da mandíbula de ratos Wistar: uma correlação com a expressão do receptor de insulina. 2011. 109 f. Dissertação (Mestrado em Ciências) - Faculdade de Medicina Veterinária e Zootecnia, Universidade de São Paulo, São Paulo, 2011.

CARRAZA, F. R. Distúrbios nutricionais crônicos: desnutrição. In: Marcondes E. Pediatria básica. 8 ed. São Paulo: Sarvier; 1994. p.635-43.

CONRADI, N. G.; SJÖSTRÖM, A.; RYDENHAG, B. Functional development of the visual system in normal and protein deprived rats. VIII. Post-natal development of optic nerve axons. Acta Physiol. Scand., v. 136, n. 4, p. 597-603, 1989.

CORDERO, M. E.; TREJO, M., GARCIA, E; BARROS, T.; ROJAS, A. M.; COLOMBO, M. Dendritic development in the neocortex of adult rats following a maintained prenatal and/or early posnatal life undernutricion. Early Hum. Dev., v. 14, n. 3-4, p. 245-258, 1986. 
EVAN, A. P.; DAIL, W. G.; DAMMROSE, D.; PALMER, C. Scanning eléctron microscopy of cell surfaces following removal of extracelular material. Anat. Rec., v. 185, n. 4, p. 433-446, 1976.

FAO. Food and agriculture organization of the United Nations, undernourishment around the world. 2012. Disponível em: <http://www.fao.org/docrep/018/i3107e/i3107e02.pdf> Acesso em: 06 Jan. 2015.

FERREIRA, A. B. H. Mini-aurélio: o dicionário da língua portuguesa. 8. ed. Curitiba: Positivo, 2010. 960 p.

GEUNA, S.; TOS, P.; BATTISTON, B.; GUGLIELMONE, R. Verification of the twodimensional dissector, a method for the unbiased estimation of density and number of myelinated nerve fibers in peripheral nerves. Ann. Anat., v. 181, p. 23-34, 1999.

GIBSON, R. S.; YEUDALL, F.; DROST, N.; MTITIMUNI, B. M.; CULLINAN, T. R. Experiences of a community-based dietary intervention to enhance micronutrient adequacy of diets low in animal source foods and high in phytate: a case study in rural Malawian children. The Journal of Nutrition, v. 133, n.11 p. 3992S-3999S. 2003.

GOBATTO, C. A. Alterações metabólicas decorrentes do treinamento físico em ratos previamente desnutridos e recuperados. 1993. 122 f. Dissertação (Mestrado em Biologia Funcional e Molecular) - Instituto de Biologia, Universidade Estadual de Campinas, São Paulo,1993.

GOMES, O. A.; CASTELUCCI, P.; FONTES, R. B. V.; LIBERTI, E. A. Effects of preand postnatal protein deprivation and postnatal refeeding on myenteric neurons of the rat small intestine: A quantitative morphological study. Autonomic Neuroscience: basic and clinical, v. 126, n. 127, p. 277-284, 2006.

GONÇALVES, L. A. Efeito da restrição alimentar e do envelhecimento sobre o sistema colinérgico cortical de ratos. 2001. 84 f. Dissertação (Mestrado em Ciências Farmacêuticas)- Faculdade de Farmácia da Universidade Federal de Minas Gerais, Belo Horizonte. 2011.

GONÇALVES, L. A.; BOLDRINI, S. C.; CAPOTE, T. S. O.; BINOTTI, C. B.; AZEREDO, R. A. MARTINI, D. T.; ROSENBERG, B.; BAUTZ, W. G.; LIBERTI, E. A. Structural and Ultra-Structural Features of the First Mandibular Molars of Young Rats Submitted to Pre and Postnatal Protein Deficiencies. The Open Dent J, v. 3, p. 125131, 2009.

GOMES, O. A.; CASTELUCCI, P.; FONTES, R. B. V.; LIBERTI, E. A. Effects of preand postnatal protein deprivation and postnatal refeeding on myenteric neurons of the rat small intestine: a quantitative morphological study. Autonomic Neuroscience v. 30 , n. $126-127$, p. 277 - 284. 2006

GRAY, H. Anatomia: o sistema nervoso periférico. 2. ed. Rio de Janeiro: Guanabara Koogan, 1988. P $741-843$. 
HABACUQUE, T. S. S. Aspectos estruturais, ultraestruturais e quantitativos dos efeitos da desnutrição proteica pré e pós-natal e da renutrição pós-natal no plexo ganglionar da traquéia de ratos. 2010. 141 f. Dissertação (Mestrado em Ciências), - Instituto de Ciências Biomédicas, Universidade de São Paulo, São Paulo, 2010.

HEDLEY-WHYTE, E. T.; MEUSER, C. S. The effect of undernutrition myelination of rat sciatic nerve. J Neuropathol Exp Neurol., v. 30, n.1, p. 130-131, 1971.

HIANE, P. A.; MACEDO, L. R.; SILVA, G. M.; BRAGA, J. A. N. Avaliação nutricional da proteína de amêndoas de bocaiúva, Acrocomia aculeata (Jacq.) Lodd., em ratos wistar em crescimento. B.CEPPA, Curitiba, v. 24, n. 1, p. 191-206, 2006.

INSTITUTO NACIONAL DE ESTATÍSTICA. (IBGE). 2015. Disponível em: $<$ http://www.ine.gov.mz/> Acesso em 13 jan. 2014.

JAHOOR, F.; BADALOO, A.; REID, M.; FORRESTER, T. Protein metabolism in severe childhood malnutrition, Annals of Tropical Paediatrics, v. 28, n. 2, p.87-101, 2008.

JULIEN, M.; ALBUQUERQUE, O.; CLIFF, J.; ARAUJO, A.; MORAIS, A. Changing patterns in pediatric mortality, Maputo Central Hospital Mozambique, 1980-1990. J. Trop. Paediatr. v. 41, n. 6, p. 366-68, 1995.

LI, H.; STEIN, A. D.; BARNHART, H. X.; RAMAKRISHNAN, U.; MARTORELL, R.. Associations between prenatal and postnatal growth and adult body size and composition. Am J Clin Nutr. v. 77, n. 6, p.1498-1505, 2003.

LUIZ, L. F. Repercussões morfológicas da subnutrição proteica pré e pós-natal e da renutrição pós-natal na mucosa lingual de ratos Wistar nas fases púberes e adulta: avaliações estrutural e da expressão do IGF-I e IGF-IR, da insulina e seu receptor. 2012, 92 f. Dissertação (Mestrado em Ciências) - Faculdade de Medicina Veterinária e Zootecnia, Universidade de São Paulo, São Paulo, 2012.

MACEDO, M. L. R.; DAMICO, D. C. S. Effects of protein fractions from Zea mays L. on development and survival of mexican bean weevil Zabrotes subfasciatus (Boh.). Insect Sci. Applic., v. 20, n. 2, p. 135-139, 2000.

MARTINI, F. H.; TIMMONS M. J.; TALLITSCH, R. B. Anatomia humana: o sistema nervoso a medula espinal e os nervos espinais. 6. ed. São Paulo: Artmed, 2009. P $361-385$.

MARTINS, H. Causas, consequências e custos da desnutrição em Moçambique. Lisboa- Portugal: Instituto de Higiene e Medicina Tropical de Lisboa, 2008, Disponível em: < http://www.ihmt.unl.pt/ >. Acesso em: 22 mar. 2013.

MIRANDA, C. M. Repercussões morfológicas da desnutrição proteica pré e pós-natal eda renutrição pós-natal sobre a lâmina epifisial e a cartilagem de ossos longos de ratos Wistar. 2006. 75 f. Dissertação (Mestrado em Ciências 
Morfofuncionais) - Instituto de Ciências Biomédicas, Universidade de São Paulo, São Paulo, 2006.

MONTE, C. M. G. Desnutrição: um desafio secular à nutrição infantil. J Pediatr, v. 76 , p. $285-297,2000$.

MONTEIRO, C. A. A dimensão da pobreza, da fome e da desnutrição no Brasil. Estudos avançados, v. 9, n. 24, p. 1995-1207, 1995.

MORGANE, P. J.; AUSTIN-LAFRANCE, R.; BRONZINO, J.; TONKISS, J.; DÍAZCINTRA, S.; CINTRA, L.; KEMPER, T.; GALLER, J. R. Prenatal malnutrition and development of the brain. Neurosci Biobehav Rev, v. 17, n.1, p. 91-128, 1993.

MORGANE, P. J.; MOKLER, D. J.; GALLER, J. R. Effects of prenatal protein malnutrition on the hippocampal formation. Neurosci Biobehav Rev, v. 26, n. 4, p. 471-483, 2002.

NÓBREGA, F. J. Desnutrição intrauterina e pós-natal. Curitiba: Panamed, 1086. 2. ed. $567 \mathrm{p}$.

OHTANI, O.; USHIKI, T.; TAGUCHI, T. KIKUTA, A. Collagen fibrilar networks as skeletal frameworks: a demonstration by cell-maceration/scanning eletron microscope method. Arch. Histol. Cytol. v. 51, n. 3, p. 249-261, 1988.

OLIVEIRA, F. Características histoquímicas das fibras musculares do $\mathrm{m}$. Gastrocnêmio de ratos wistar desnutridos submetidos à lesão térmica. 2006. 140 f. Tese (Doutorado em Ciências) - Instituto de Ciências Biomédicas, Universidade de São Paulo, São Paulo, 2006.

PARADA-SIMÃO, T. R.; OLIVEIRA, F.; PACHECO, M. E.; ALVES, P. H. M.; LIBERTI, E. A. Effects of protein malnutrition on muscle fibers of the brachial biceps and medial pterygoid of Wistar rats. J. Morphol. Sci., v. 28, n. 3, p. 196-203, 2011.

PIRES, C. V.; OLIVEIRA, M. G. A.; ROSA, J. C.; COSTA, N. M. B. Qualidade nutricional e escore químico de aminoácidos de diferentes fontes proteicas. Ciênc. Tecnol. Aliment., Campinas, v. 26, n. 1, p. 179-187, 2006.

RACELA, A. S.; GRADY, H. J.; HIGGINSON, J.; SVOBODA, D. J. Protein deficiency in rhesus mokeys. Am J Pathol, v. 49, n. 3, p. 419-443, 1966.

REEVES, P. G.; NIELSEN, F. H.; FAHEY G. C. JR.; AIN-93 purified diets for laboratory rodents: final report $f$ the American Institute of Nutrition ad hoc writing committee on the reformulation of the AIN-76 ${ }^{a}$ rodent diet. J. Nutr., v. 123, n. 11, p. 1939-1951, 1993.

SAWAYA, A. L. Desnutrição: consequências em longo prazo e efeitos da recuperação nutricional. Estudos Avançados, v. 20, n. 58, p. 147-158, 2006. 
SGARBIERI, V.C. Métodos de avaliação da qualidade nutricional dos alimentos. In: SGARBIERI, V.C. Alimentação e nutrição: fator de saúde e desenvolvimento. São Paulo: Almed, 1987. p. 250-261.

SHRADER, R. E., ZEMAN, F. J. Skeletal development in rats as affected by maternal protein deprivation and postnatal food supply. J. Nutr. v. 103, n. 5, p. 792-801,1973.

SIMA, A.; SOURANDER, P. The effect of early undernutrition on the caliber spectrum of the rat optic nerve. A morphometric ultrastructural study. Acta Neuropathol. v. 28, n. 2, p. 151-160, 1974.

SIMA, A.; OLSSON, Y.; SOURANDER, P. Experimental observations in peripheral nerves in undernourished rats. Acta Pathol. Microbiol. v.79, n. 3, p. 310, 1971.

SIMÕES, L.S.; BOLDRINI, S.C.; BINOTTI, C.B.; CAPOTE, T.S.O.; LIBERTI, E.A. Impact of Pre and Postnatal Protein Energy Deprivation on Structure of the Trigeminal Ganglion of Weanling Rats. The Open Nutrition Journal, v. 3, n. 1, p. 14, 2009.

SPANHEIMER, R.; ZLATEV, T.; UMPIERREZ, G.; DIGIROLAMO, M. Collagen production in fasted and food-restricted rats: response to duration and severity of food deprivation. J. Nutr., v. 121, n. 4, p. 518-524, 1991.

SPENCE. Anatomia humana básica: sistema nervoso periférico. 2. ed. São Paulo: Manole, 1991. P 419 - 444.

STERN, W. C.; FORBES, W. B.; RESNICK, O.; MORGANE, P. J. Seizure susceptibility and brain amine levels following protein mal nutrition during development in the rat. Brain Res. V. 79, N. 3, P. 375 - 384, 1974

STRATTON, R. J. Elucidating effective ways to identify and treat malnutrition. Proc Nutri Soc. v. 64, n. 3, p. 305-311, 2005.

UNITED NATIONS. The Millennium Development Goals Report 2007. New York; 2007. Disponível em: <http://www.un.org/millenniumgoals/pdf/mdg2007.pdf>. Acesso em: 06 Jan. 2015

UNITED NATIONS CHILDREN'S FOUND. The state of the world's children. 2015. Disponível em:

<http://www.unicef.org/rightsite/sowc/pdfs/statistics/SOWC_Spec_Ed_CRC_TABLE \%202.\%20NUTRITION_EN_111309.pdf> Acesso em: 18 Jan. $20 \overline{15}$.

VIAU, V.; BINGHAM, B.; DAVIS, J.; LEE, P.; WONG, M. Gender and puberty interact on the stress-induced activation of parvocellular neurosecretory neurons and corticatropinreleasing hormone messenger ribonucleic acid expression in the rat. Endocrinology, v. 146, n. 1, p. 137-146, 2005.

VINCENT, M.; RADERMECKER, M. A. Histologic investigation of muscle tissue in Kwashiorkor. Am J Trop Med Hyg, v. 8, n.4, p. 511-517, 1959. 
WFP. WORLD FOOD PROGRAMME. Hunger map. 2011. Disponível em:

$<$ http://www.wfp.org/students-and-teachers/teachers/blog/new-teaching-tool-hungermap-2011>. Acesso em: 10 nov. 2014.

WFP. WORLD FOOD PROGRAMME. Hunger map. 2014. Disponível em:

<http://documents.wfp.org/stellent/groups/public/documents/communications/wfp268 726.pdf >. Acesso em: 10 nov. 2014.

WHO. WORLD HEALTH ORGANIZATION. Joint FAO/WHO expert committee on nutrition insufficiency. Brain Res. v. 257, n. 2, p. 151-75,1982.

WHO. WORLD HEALTH ORGANIZATION. Nutrition Landscape Information System. 2010. Disponível em:

<http://apps.who.int/nutrition/landscape/report.aspx?iso=moz> Acesso em 18 Jan. 2013

WOODROOF, J. G. Composition and nutritive value of peanuts. In: AUTOR, A. B. Peanut production, processing, products. 3. ed. United Kingdom: Avi Publishing Co, 1983. p.165-179.

ZAR, J. H. Biostatistical analysis. 2. ed. New Jersey: Prentice Hall, 1984. 718 p. 